Revista de la red interuniversitaria de estudios sobre las literaturas rioplatenses contemporáneas en Francia

$18 \mid 2018$

El río y la ciudad

\title{
Pablo, entre la tierra y el río
}

Políticas públicas de la memoria en el Río de la Plata

\section{Myrna Insua}

\section{(2) OpenEdition}

\section{Journals}

Edición electrónica

URL: http://journals.openedition.org/lirico/6070

DOI: $10.4000 /$ lirico.6070

ISSN: 2262-8339

\section{Editor}

Réseau interuniversitaire d'étude des littératures contemporaines du Río de la Plata

\section{Referencia electrónica}

Myrna Insua, "Pablo, entre la tierra y el río », Cuadernos LIRICO [En línea], 18 | 2018, Publicado el 02 diciembre 2018, consultado el 10 diciembre 2020. URL : http://journals.openedition.org/lirico/6070 DOI : https://doi.org/10.4000/lirico.6070

Este documento fue generado automáticamente el 10 diciembre 2020.

\section{(c) (i) (9)}

Cuadernos LIRICO está distribuido bajo una Licencia Creative Commons Atribución-NoComercialSinDerivar 4.0 Internacional. 


\title{
Pablo, entre la tierra y el río
}

\author{
Políticas públicas de la memoria en el Río de la Plata
}

\author{
Myrna Insua
}

Una persona a la que puedo nombrar no está presente ni ausente. Jean-Louis Deotte ${ }^{1}$

1 Algunos nombres resuenan y se inscriben en nuestro imaginario societal sin que nos demos cuenta. Un hecho puntual, conflictivo o no, un objeto que nos interroga, una performance artística, una narración que violenta el espacio de lo privado para trascender públicamente, constituyen una serie de hitos que, por su imposible repetición o por su sumatoria, actúan como dispositivos que poco a poco van construyendo una entidad y sus fronteras. Uno de esos nombres que, decíamos, tintinean en nuestras mentes y que tal vez llegado el momento evocaremos como si hubiera estado desde siempre en los márgenes de nuestra historia común, es el de Pablo Míguez.

2 Pablo, lo hemos aprendido en estos últimos años, nació el 1 de marzo de 1963. Era hijo de Juan Carlos Míguez y de Irma Beatriz Márquez Sayago. Tenía una hermana menor llamada Graciela, y un medio hermano, Eduardo, nacido de la unión de su mamá con Jorge Capello. Jorge e Irma eran militantes del Ejército Revolucionario del Pueblo (ERP) y vivían en Avellaneda, provincia de Buenos Aires. El 12 de mayo de 1977, a la madrugada, en un vasto operativo del ejército, fueron secuestrados de su casa. Junto con ellos también se llevaron ilegalmente a Pablo y a Luis Munitis. Todos permanecen desaparecidos. Pablo tenía 14 años... Hoy lleva un número añadido a su nombre: Pablo Antonio Míguez Márquez, legajo CONADEP 7231. 


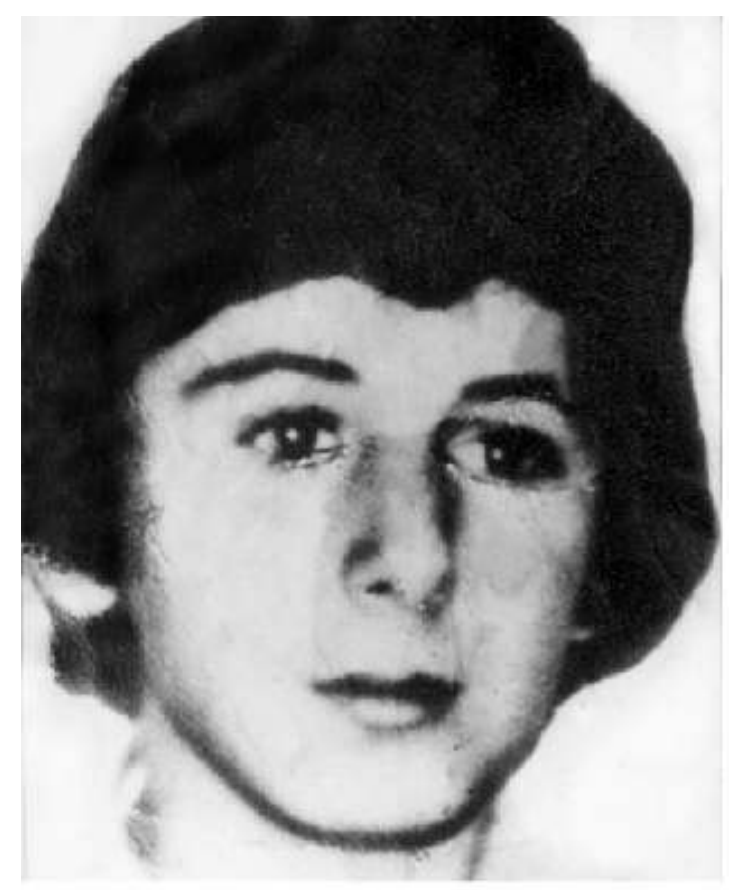

\section{Pablo Antonio Miguez \\ 12-5-77}

Imagen 1. Foto destinada a la búsqueda del desaparecido²

3 Su nombre y su número de legajo nos hablan de su vida trunca, corolario de la acción del represor. Nos retrotraen hasta sus últimos padecimientos, y nos conducen desde su existencia real hasta su envoltorio fantasmagórico. Nos hablan de su desaparición y de su presencia intangible. De su vida y de su incompleta aparición. Nos sugieren quién fue el adolescente que cursaba el segundo año del colegio industrial de Avellaneda, pero, más precisamente, nos muestran cómo el Movimiento de Derechos Humanos ${ }^{3}$ y las políticas públicas del Gobierno de la ciudad de Buenos Aires han concebido el significante Pablo Míguez. Pablo, el que no está, en su sola enunciación recorta un espacio en el interior de un continente de sentidos cuyos límites simbólicos son múltiples, difusos y ciertamente contradictorios. Pablo, representado, es en la actualidad una continuidad de aquello que lo representa, de ese acero que se sitúa en el entredós bordado por el Río y su orilla. Pablo es hoy un adolescente eterno, un emergente de La Reconstrucción del retrato de Pablo Míguez y su memoria encuentra anclaje en las aguas comprometidas por los vuelos de la muerte ${ }^{4}$.

La Reconstrucción del retrato de Pablo Míguez ${ }^{5}$ es una escultura emplazada en el Parque de la Memoria, espacio público erigido para conmemorar a los desaparecidos y asesinados por el terrorismo de Estado que asoló la Argentina desde mediados de los años 70 hasta el regreso de la democracia constitucional en diciembre de 1983. Construido en cemento y adulterado por la hierba, este espacio memorial y artístico está ubicado en la costanera porteña, frente al Río de la Plata, sin intermediación alguna. La estatua, La Reconstrucción..., tiene aproximadamente las dimensiones reales del cuerpo de un adolescente medio de 14 años $(1,70 \times 0,45 \times 0,40 \mathrm{~m})$. Fue creada por la artista visual Claudia Fontes y asociada desde su concepción al lugar del emplazamiento definitivo. La artista empleó para su obra el acero inoxidable pulido a espejo, material que desde su lugar de instalación (70 metros aguas adentro contados a partir de la plataforma de observación) produce el reflejo del agua movediza del Río de La Plata en la escultura y 
simultáneamente de la escultura en el Río, borrando así, el inicio de la una y el comienzo del otro.

El interés que produce esta estatua se origina en que ella, más que cualquiera de las otras obras que forman parte del conjunto poli-escultural del Parque de la Memoria, se sitúa en el punto radical de fractura entre el reconocimiento y la sensibilidad del sentido que Gilles Deleuze atribuye a la génesis del acto de pensar y al pensamiento mismo: al "objeto del encuentro fundamental". La Reconstrucción... no solo actúa como objeto de encuentro por su relación fáctica entre el río y la ciudad, el espectador de la orilla y el de la lejanía, sino que es el lugar mismo de creación del encuentro e irrumpe en el pensamiento cuando este es incapaz de producir el reconocimiento del objeto del acto de pensar forzando de esta manera a que el mundo de lo sensible intervenga. La Reconstrucción... rememora donde no hay que rememorar, donde no existe experiencia de lo sensible, ni materia empírica para formar un recuerdo. Pablo Míguez, su representación formal, no es un objeto sensible sino el objeto de lo sensible. El punto desde el cual cada expresión individual debe relacionarse con lo colectivo para iniciar así las condiciones de un trabajo de conjunto que permita otorgarle una entidad a la memoria, una entidad al desaparecido como un continente universal y una entidad a este joven desparecido en particular. Ahora bien, ¿cuáles son las expresiones memoriales que rodean literal y simbólicamente $L a$ Reconstrucción... y hacen posible la atribución de sentido al cuerpo que se propone enunciar?

6 Para esbozar un intento de respuesta, primeramente, mencionaremos el proceso que condujo a un sector del MDDHH a reclamar la construcción de un espacio memorial con las características del actual Parque de la Memoria. En una segunda etapa, nos concentraremos en las particularidades de la escultura de Pablo Míguez y en las ambigüedades que de ella emergen en el terreno de la utilización política de lo sensible. Para acceder a la obra de Fontes no es posible posicionarse exclusivamente desde la teoría del arte y analizar desde allí sus repercusiones. La obra escultural, al unirse a la dinámica del Río de la Plata para formar un todo, traslada las posibles lecturas que de ella puedan hacerse desde la estética a la política, es decir desde lo creativo-valorativo hasta el terreno de lo político valorativo. De ahí que el contexto de producción y el entorno escultórico, museológico y arquitectural del emplazamiento de La Reconstrucción..., sean inseparables tanto del impacto que ella produce en el observador autor o participe del acto memorial, que de la entronización en la memoria social de la figura de Pablo Míguez.

\section{Acciones de resistencia, acciones de justicia y acciones memoriales: El Río de la Plata, anclaje memorial de la desaparición}

Los lugares de la memoria viven gracias a su capacidad de metamorfosis. PIERRE NORA ${ }^{7}$

7 La instauración de un parque destinado a "la memoria" en los límites fluviales de la ciudad, marca un clivaje en las estrategias de evocación del pasado reciente esgrimidas hasta finales de los años 90 por el MDDHH. La ley 46, sancionada por la legislatura de la Ciudad Autónoma de Buenos Aires en julio de 1998, que destina una franja costera del Río de la Plata a la implantación de un Monumento a las Víctimas del Terrorismo de Estado8, 
en el corazón de un espacio concebido como un Parque poli escultural de la Memoria, puede considerarse como la primera acción de política pública de características puramente memoriales cuyo objetivo último es fundar artificialmente, en un nudo de evocación real -el Río de la Plata-, un lugar emblemático de memoria/transmisión orientado doblemente a la acogida de los impulsores del proyecto -las familias y amigos de las víctimas homenajeadas- y al conjunto de la sociedad, particularmente a las generaciones nacidas en democracia y a las venideras.

\section{Acciones colectivas del MDDHH. Generalidades.}

8 Desde su nacimiento como movimiento social, cuya fecha colocamos en el 30 de abril de 1977, día en el cual las madres de desaparecidos se vuelven autónomas y se nombran a sí mismas como Madres de Plaza de Mayo, el MDDHH organiza sus conductas conflictivas identitarias culturalmente orientadas hacia la búsqueda de "sus" desaparecidos?. Esta búsqueda se regula en el marco de un escenario de acciones colectivas delimitado por la articulación interna de hegemonías culturales y liderazgos éticos-políticos. A su vez, estas relaciones mutantes y complejas organizan un calendario de conmemoraciones colectivas ${ }^{10} \mathrm{y}$ un cierto repertorio de acciones en coherencia con la articulación de sus actores y la hegemonía imperante, la cual atribuimos hasta los años 2000 a la Asociación Madres de Plaza de Mayo. En grandes líneas, y haciendo referencia exclusivamente a las acciones que tienen un porte netamente identitario, dentro de este repertorio podemos encontrar las acciones colectivas de resistencia (A.C.R) como por ejemplo la primera configuración de las marchas que se suceden cada jueves alrededor de la pirámide de la Plaza de Mayo y las llamadas Marchas de la Resistencia, organizadas ambas a partir del actor Madres ${ }^{11}$. Un segundo grupo lo constituyen las acciones colectivas reivindicativas (A.C.Re) cuyo objetivo es la denuncia de la desaparición como una consecuencia querida del plan sistemático de exterminio ejecutado por los responsables de la del Terrorismo de Estado en Argentina. Por último, es posible identificar un tercer grupo compuesto por las acciones colectivas en reclamo de justicia (A.C.R.J.). Este grupo incluye tanto las acciones reivindicativas cuando se transforman en denuncias contra la impunidad judicial y política como todas aquellas acciones de justicia que enlazan demandas del pasado y del presente. La retroalimentación de estos tres tipos de acciones involucra distintamente la participación de los diversos actores del Movimiento en la arena publica, y forja en la gestión de este proceso múltiples disposiciones memoriales que se incorporan al imaginario social con intensidad y grado disímil. En otras palabras, cada actor aporta en su manera de ejecutar la acción su propia huella identitaria.

El 10 de diciembre de 1997, día internacional de los DDHH, cuando los nueve organismos de derechos humanos ${ }^{12}$ gestores del Monumento a las Victimas... presentaron a la legislatura porteña la iniciativa que sería aprobada unos meses más tarde, el MDDHH y su actividad pública tenían ya una conformación muy distinta a aquella que los caracterizaba en los años de resistencia y en los primeros de la transición democrática. En este período de crisis política, social y económica, el abanico de posibilidades de acción se había restringido forzando al MDDHH a imaginar nuevas acciones, nuevas formas de reivindicación y de intervenciones públicas. Las Madres seguían marchando y "resistiendo" pero las expectativas de castigo judicial vislumbradas a la ocasión del Juicio a las Juntas de 1985 y la apertura simultanea o sucesiva de cientos de causas involucrando a los miembros de grupos de tareas y a los demás responsables de las fuerzas armadas y 
de la policía, se habían desvanecido brutalmente. Las llamadas leyes de impunidad impulsadas por el gobierno radical (Punto Final, Obediencia Debida) y la gracia presidencial del presidente justicialista Carlos Menem que diera lugar al indulto de los comandantes condenados, habían vuelto casi imposible la persecución legal en cualquier otro crimen que no fuera el de secuestro y sustracción de la identidad de los hijos de desaparecidos. Por ese entonces, en lo que concierne a los crímenes de lesa humanidad cometidos en el pasado reciente, los tribunales de la Nación solo aceptaban demandas de habeas data, presentaciones que -es importante recordar-, los familiares realizaban con bastante escepticismo. Un escepticismo que diríamos era tan grande como aquel que los invadía cuando, veinte años antes, presentaban habeas corpus y afrontaban el frío rechazo de los jueces. En los 90' se mantenía abierta una instancia judicial, es verdad, pero a sabiendas de que estos juicios que se conocieron como Juicios de la Verdad eran juicios de los cuales no se podía esperar una condena.

Si hay algo que caracteriza al MDDHH argentino es la capacidad de generar constantemente oberturas y propulsar las fallas en el sistema de impunidad a su paroxismo. Así, al mismo tiempo que se cerraban los canales judiciales, la energía que no podía depositarse en acciones de justicia algunos actores -particularmente los amigos y compañeros de los desaparecidos- la volcaron en importantes conmemoraciones en honor de los ausentes y estas tuvieron lugar, ya no en las plazas sino en las universidades, los barrios y los sindicatos, identificando de esta manera a las víctimas con el sector en el cual militaban en el momento de su secuestro. Mas importante aún: por esos años los hijos de desparecidos, asesinados y exiliados se organizaron colectivamente como H.I.J.O.S (Hijos por la identidad y la Justicia contra el Olvido y el Silencio) e hicieron irrupción en la esfera pública.

\section{El Río de la Plata, lugar de memoria}

11 A mediados de los 90', este mapa de gestión de la reivindicación del desaparecido por parte del MDDHH se había visto afectado también por un factor externo: las declaraciones del capitán de corbeta Adolfo Francisco Scilingo al períodista Horacio Verbitsky. Estas declaraciones fueron publicadas en un libro $-E l$ vuelo- $\mathrm{y}$ difundidas generosamente por todos los medios de comunicación nacionales e incluso internacionales. Scilingo describía la metodología de la masacre desde el lugar del ejecutor y si bien todo lo que el marino mencionaba no era nuevo para los integrantes del MDDHH ni para los familiares no organizados colectivamente, dado que los sobrevivientes de los distintos campos clandestinos de tortura y exterminio, y en particular aquellos liberados de la Escuela de Mecánica de la Armada (ESMA), ya habían dado cuenta de todo lo que se había vivido en esos lugares de excepción y se evaluaba claramente que una de las metodologías más utilizadas como destino final de los ausentes era la de arrojar los cuerpos adormecidos desde un avión hacia las aguas del Río de la Plata o del Océano Atlántico, la voz de quien había participado de esos vuelos tenía una dimensión especial: si uno de "ellos" lo confesaba, entonces era verdad. Paradójicamente, el represor venía a legitimar a la víctima sobreviviente. Decía Scilingo en una carta dirigida al dictador Jorge Rafael Videla:

En 1977, siendo teniente de navío, estando destinado en la Escuela de Mecánica, con dependencia operativa del Primer Cuerpo de Ejército, siendo usted el Comandante en Jefe y en cumplimiento de órdenes impartidas por el Poder Ejecutivo cuya titularidad usted ejercía, participé de dos traslados aéreos, el primero con 13 subversivos a bordo de un Skyvan de la Prefectura, y el otro con 17 terroristas en un 
Electra de la Aviación Naval. Se les dijo que serían evacuados a un penal del sur y por ello debían ser vacunados. Recibieron una primera dosis de anestesia, la que sería reforzada por otra mayor en vuelo. Finalmente, en ambos casos fueron arrojados desnudos a aguas del Atlántico Sur desde los aviones en vuelo ${ }^{13}$.

En diálogo con Verbistky, el marino no solo sostenía lo dicho en esta misiva (que nunca encontró respuesta de parte de su destinatario), sino que narraba con detalles los dos vuelos en los cuales había participado y se aventuraba a exponer el ritmo con el cual se realizaban los "traslados", eufemismo que da cuenta de los últimos momentos de los desaparecidos y de la cosificación de estos en manos de los victimarios:

H.V. - ¿Qué cantidad de personas calcula que fueron asesinadas de ese modo?

S. -De 15 a 20 por miércoles.

H.V. ¿¿Durante cuánto tiempo?

S. -Dos años.

H.V. - Dos años, cien miércoles: de 1500 a 2000 personas. ${ }^{14}$

Scilingo nunca dejó de justificarse, expresando su obediencia a la jerarquía, ni dejó de llamar subversivos o terroristas a quienes se le oponían ideológicamente. Incluso consideraba que los vuelos era una muerte "cristiana". Pero nada de todo esto impidió que gran parte del MDDHH se aferrara a dos aspectos salientes de sus dichos: uno, Scilingo confirmaba que al interior de la ESMA había un registro de desparecidos; Dos, el represor afirmaba que, en la ESMA, los que "se les quedaban muertos adentro" eran quemados y que la mayoría de los secuestrados "trasladados" eran eliminados a través de los vuelos. Simbólicamente, entonces, el Río de la Plata se fortalecía en la subjetividad de muchos familiares como la imagen de la última morada de sus seres queridos $\mathrm{y}$, aunque no fuera dicho explícitamente, adquiría el estatus de tumba fluvial.

\section{Acuerdos y discrepancias acerca de la monumentalización de la memoria}

Probablemente el marco sociopolítico descripto en el cual se encuadraron las declaraciones del militar y las consecuencias inmediatas que estas produjeron, forjaron las preguntas que estuvieron en el origen del nacimiento del proyecto legislativo: ¿Cómo recordar a los desparecidos? ¿Quién recuerda? ¿Qué voces están autorizadas a poner en palabras el recuerdo? ¿Como se perdura el recuerdo? La idea de la transmisión de la memoria comenzaba entonces a hacerse un lugar necesario en el conjunto de estrategias de una parte de las organizaciones y, coincidentemente, el poder político representado tanto en el Jefe de Gobierno como en los legisladores de la Ciudad de Buenos Aires comenzaba a ser visto por esta ala del MDDHH como un aliado con el cual era posible establecer una acción conjunta que trascendiera en el tiempo. Para que esto fuera así, mucho tuvo que ver que, en ese entonces, la Jefatura de la Ciudad estaba en manos de un exfiscal federal -Aníbal Ibarra- que se había manifestado públicamente contra los indultos señalándolos como inconstitucionales y que había tenido entre sus funciones la acusación de apropiadores de niños. Paralelamente, la Dirección General de Derechos Humanos de la Ciudad estaba encabezada por una militante exiliada -Gabriela Alegre-que mantenía estrechas relaciones con los activistas de derechos humanos. El proyecto de Monumento a las victimas... surgió entonces de una necesidad de trascender el presente y fue escrito conjuntamente por múltiples manos. Por primera vez se habla de gestión mixta y no se le exige al Estado una toma de posición determinada, sino que se coordina con él un espacio que se quiere abierto hacia el futuro, para el momento en el cual -por 
razones prácticas y biológicas- los activistas no puedan sostener con su presencia el recuerdo de quienes son el objeto central de sus memorias.

Resumiendo: En un período signado para el MDDHH por la creciente desesperanza que traían consigo, entre otros emergentes, la sucesión de infructuosas batallas judiciales en reclamo de condena para los autores de los crímenes de secuestro, tortura y desaparición y el desinterés de gran parte de la población por "los derechos humanos" y el pasado reciente, el Parque y su Monumento se levanta como un jalón en un abanico de acciones colectivas que hasta ese entonces estaban hegemónicamente centradas en acciones de resistencia y de justicia. Acciones que ya habían dejado tanto en los cuerpos de los actores como en la esfera pública, y por ende en el imaginario de la lucha por los derechos humanos en Argentina, marcas indelebles y altamente simbólicas como el pañuelo blanco, la silueta de los desaparecidos o los escraches ${ }^{15}$ de los H.I.J.O.S. pero que, para algunas organizaciones del movimiento, resultaban insuficientes por no representar su posicionamiento político-memorial. Así, al considerar que debían encontrar en el corto plazo un complemento a las acciones ya conocidas, que estuviera signado por la impronta institucional y que, de esta manera, persistiera más allá de la acción de los agitadores de la memoria del pasado reciente, este grupo de organizaciones hizo posible la emergencia de acciones memoriales institucionales museísticas y monumentales (A.M.I.M.M)

Si la apertura de oportunidades políticas, por todo lo mencionado, podía considerarse favorable a un cambio de dinámica en el modo de hacer memoria, para influenciar al actor estatal en vistas de impulsar en una dirección determinada una política pública de estas características, el MDDHH tuvo que organizarse simultáneamente en dos esferas bien distintas: Una exterior centrada en la coordinación de estrategias con otros actores, principalmente el legislativo, y otra orientada hacia adentro del propio movimiento, que implicaba, por una parte, generar el marco propicio para dialogar con los sectores que no compartían ideológicamente esta manera de hacer memoria, algo que veremos resultara imposible y, por otra, establecer un zócalo de acuerdos entre aquellos 9 organismos que llevarían adelante la batalla por la construcción de un Muro de la memoria. En este caso la estrategia resultara exitosa y duradera.

Todo movimiento social, y el de derechos humanos no es una excepción, es un conjunto de actores naturalmente en conflicto que busca que su cosmovisión identitaria triunfe frente a las otras y esto conlleva a que internamente las disputas se orienten a establecer cuál es la identidad que actúa como portavoz del reclamo. En este caso, desde su primera formulación, el proyecto de Monumento a las víctimas... fue la expresión de una lucha intestina por imponer las memorias de unos y otros. Simplistamente podría resumirse en el enfrentamiento de dos bloques: los pro y los contra Monumento, pero en estos dos reagrupamientos cada actor fue la expresión de una palabra diferente. La asociación Madres de Plaza de Mayo, la asociación de Ex Detenidos Desaparecidos y los H.I.J.O.S. se opusieron a la idea misma de un Monumento sin que resultara de mayor importancia para este rechazo el lugar elegido -la zona costera del Río de la Plata- para su emplazamiento. Esta posición no era nueva para la Asociación Madres de Plaza de Mayo y estaba claramente formulada en las 11 consignas políticas históricas de este actor:

Rechazamos los homenajes póstumos. Rechazamos las placas y los monumentos porque eso significa enterrar a los muertos. El único homenaje posible es levantar sus banderas de lucha y continuar su camino. Los homenajes póstumos sólo sirven para que los que garantizaron la impunidad, hoy laven sus culpas. El único monumento que podemos levantar es un inquebrantable compromiso con sus ideales ${ }^{16}$. 
18 A ello se sumaba que, en términos de la Asociación de Madres, individualizar los desaparecidos colocando sus nombres en una placa o en un Monumento se opone a la reivindicación global y sin distinciones de pertenencias ideológicas, políticas o sociales de los desparecidos representada en el número: 30.000. Por ello desde el primer momento amenazaron con borrar los nombres de sus hijos si estos aparecían inscriptos junto a los otros. Por su parte la Asociación de Ex Detenidos Desaparecidos se oponía a esta iniciativa porque provenía de un acuerdo con el Estado y si ella no permitía terminar con la fase de impunidad que se estaba viviendo, mucho menos podía constituirse en un objeto de transmisión viable. Esta organización exigía, además, que a los nombres de los desparecidos se les agregara, en toda conmemoración de estas características, que tuviera la pretensión de perdurar, los nombres de los represores y de los diputados que habían votado las leyes de Obediencia Debida y de Punto Final.

19 En cuanto a los H.I.J.O.S., estos no se oponían a la idea del Monumento a las víctimas... ni a un Parque escultural memorial sino al hecho de que fuera una iniciativa pactada con el gobierno de turno:

No estamos en contra de ningún tipo de monumento, tirar una flor al río o poner una placa, pero si van a hacer una herida en la tierra (la forma que va a tener el monumento), la herida no es solo por los que no están, sino porque los asesinos están libres, y porque había un proyecto de país diferente. Y la gente que va a disponer del dinero para que se construya este monumento es la que profundiza el modelo contra el cual luchaban los desparecidos ${ }^{17}$.

20 A diferencia de la Asociación de Madres, ni los ex Detenidos Desaparecidos ni los H.I.J.O.S se posicionaron públicamente contra los organismos que portaban la Ley 46. Sin embargo, esto no evitó que el 24 de marzo de 1999, día en el cual se colocó en el predio de la costanera la piedra fundamental del Monumento a las Victimas..., estas organizaciones junto a la Coordinadora contra la violencia Policial e Institucional (CORREPI) participaran de un contra acto bajo el lema "Estos son los que dieron el perdón". El contra acto en repudio al gobierno de la ciudad se realizó mientras Mabel Gutiérrez, presidenta por ese entonces de la asociación de Familiares de Desaparecidos y Detenidos por Razones Políticas, leía el documento acordado por la Comisión Pro-Monumento a las Victimas del Terrorismo de Estado. Esta confrontación pública entre actores del MDDHH -la primera desde su conformación- dejó un saldo amargo para todos los participantes. No solo porque opuso militantes de una misma causa, sino además porque el gobierno ejecutivo de la ciudad y un cierto número de legisladores no habían cumplido en parte con las promesas realizadas a las organizaciones de derechos humanos. En la placa que acompañaría la piedra fundamental se suponía que estaría escrito "Aquí se construirá el monumento a las víctimas del terrorismo de Estado en reivindicación de sus luchas y sus ideales”. Esto no sucedió y la historia quiso que mientras se instituía el Monumento y se lanzaba públicamente el Concurso de Esculturas que daría vida al Parque de la Memoria, el Movimiento Ecuménico por los Derechos de Hombre constituido en garante de los acuerdos asumidos por la gestión mixta, pedía informes a la legislatura por dicho incumplimiento ${ }^{18}$.

21 En suma, en los orígenes de las acciones memoriales monumentales e institucionales que vendrán luego a imponerse con una cierta naturalidad en los años 2000 y a adquirir el estatus de marca característica del accionar del MDDHH, nos encontramos, primeramente, con alianzas estratégicas casi inéditas entre actores que se sostienen con desconfianza $y$, en segundo lugar, con una disputa fratricida por imponer una manera 
monumental y particular de representar la desaparición. Y lejos de ser una anomalía, estos antecedentes no hacen más que reafirmar que el acto de recordar no se sustenta en un continente vacío, sino que se constituye apoyándose en un objeto del recuerdo cuya consistencia significativa no es univoca, ni inmóvil, ni manejable por quien quiere venir a llenar ese espacio.

\section{Arte y persistencia de la memoria}

Como hemos visto, si la primera parte del proceso de emergencia de monumentalización de la memoria fue particularmente compleja debido a las diferentes estrategias políticoideológicas de alianzas esgrimidas tanto por las organizaciones de derechos humanos como por los actores políticos, el Monumento a las víctimas... y el Parque poliescultural de la Memoria, al imponerse más allá de las disputas como una huella perenne, al transformar la dinámica memorial del MDDHH, dislocaron el lugar del actor memorial hegemónico y formalizaron una nueva etapa a partir de la cual un grupo de organismos comenzaría a trabajar conjuntamente debatiendo no solo los aspectos políticos de las acciones reivindicativas de la memoria de los desaparecidos y asesinados sino también los aspectos artísticos y creativos que rodean a estas memorias y las vuelven o no trasmisibles. La complejidad de este proceso no se limitó entonces a la discusión de si era licito o no construir un monumento de piedra con los nombres de los desaparecidos y asesinados allí inscriptos y de si se aceptaba o no que fuera financiado por el Estado en su representación municipal sino que aparecieron otros conflictos orientando el eje del debate hacia la esencia misma de la necesidad de un lugar destinado a la manifestación de "las memorias" y más específicamente a la potencialidad del arte como herramienta de representación de la desaparición. Con respecto a determinar el mejor terreno físico y simbólico como sustrato a la evocación, la disponibilidad inmediata de las tierras costeras y la posibilidad de intervenir conjuntamente en ese espacio con la Universidad de Buenos Aires hizo que como telón de fondo del debate se instalara una particular mirada del río y hacia el río: la centralidad del Río de la Plata, querida por los actores del MDDHH, se incorporó como un elemento inseparable de la forma concreta en la cual se iba a rendir homenaje a las víctimas. Así, en su carácter de materialidad constitutiva de esta fase e igualmente testigo de lo que se quiere recordar, el Río de la Plata prorrumpe con una fuerza inédita consagrándose como "el lugar del" recuerdo y "el lugar para" conmemorar. El río pasa a ser ese lugar donde, haciendo honor a su etimología, los "recordantes" esperaban que recordar conduzca "de nuevo" a hacer latir el corazón por aquellos que no están.

En consecuencia, el proyecto arquitectónico y paisajístico que fue seleccionado a partir del "Concurso Nacional de Ideas" impulsado por la Facultad de Arquitectura de la Universidad de Buenos Aires, y que se llevó a cabo durante 1998 con el objetivo de dar vida al Parque de la Memoria, tomo en consideración este deseo memorial y concibió el Monumento... como una herida abierta en la tierra situada a la manera de un plano inclinado sobre una colina de unos 6 metros de alto. Por su disposición, esta "herida" conduce directamente hasta las orillas del Plata. Más aún: asociando los nombres que en ella figuran, nos "traslada" desde las victimas hacia su presunto destino final, imponiendo de alguna manera una lectura memorial global, e incluso nacional, sobre la suerte corrida por solo una parte de los que no aparecieron. En este sentido, también hay un giro simbólico que da cabida a un cambio en el registro de las acciones memoriales puesto que, 
a principios de la democracia formal, la imagen asociada a los últimos momentos de los desaparecidos eran las fosas comunes.

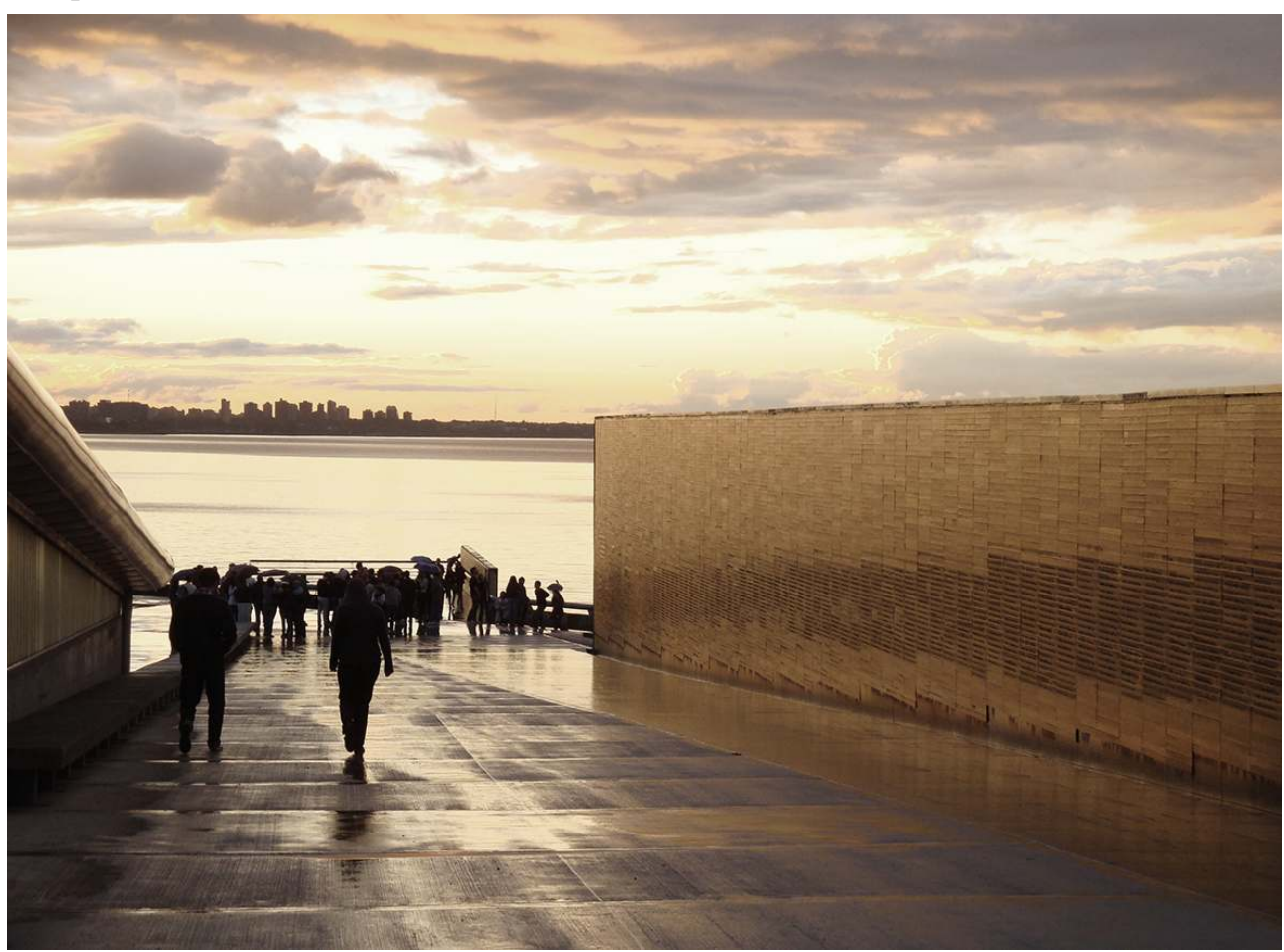

Imagen 2. Vista desde el Monumento hacia la explanada de observación de la escultura $L a$ Reconstrucción...19

Los artífices arquitectónicos del Parque de la Memoria -Alberto Varas, J. Lestard, M. Baudizzone y asociados- cuyo particular interés era devolver al uso y goce publico la zona aledaña a la Ciudad Universitaria, consideraban que "a través de la intervención paisajística, de los trazados y de la trabajosa y lenta construcción de la colina artificial [... ], se recrea el esfuerzo necesario para la construcción de una sociedad y un estado no violentos" ${ }^{20}$. Es decir que el contenido simbólico del río como espectro de la muerte fue un elemento discursivo cuyo significado no fue consensuado por todos los actores sino atribuido exclusivamente desde los esbozos del proyecto por los miembros de la comisión Pro-Monumento y por quienes la sostuvieron: "Este monumento se levantará junto al río porque en sus aguas fueron arrojadas muchas de las víctimas" afirmaba la Comisión en el documento leído en el acto de colocación de la piedra fundamental. Asociado al horror, el río había "perdido su inocencia" y para exorcizarlo era necesario que fuera coligado a la reivindicación de los ausentes y este aspecto solo podría ser introducido por el arte como acción de redención. Las esculturas que rodearían la "herida abierta" sacarían a los "desaparecidos y asesinados de su anonimato" y reflejarían "los proyectos e ideales de libertad y justicia social por los que lucharon" ${ }^{21}$. Con ese criterio fueron seleccionadas las obras ganadoras del concurso de esculturas y aquellas elegidas especialmente por fuera del proceso de competición. Desde los inicios, se piensa a su vez en un público activo que pueda comprender el mensaje sin necesidad de una literalidad perfecta. Un público que tendrá frente a sus ojos un espacio disociado del ritmo cotidiano de la ciudad y en el cual las diversas obras de arte lo invitaran a la reflexión, presumiblemente sin dirigismos ni atribución previa de sentido. 
trando en el tercer eje del debate y consagrándonos particularmente al aspecto artístico-memorial, podemos afirmar que el diseño de esta otra cara de la acción memorial tampoco estuvo desprovisto de contradicciones. Como escribe con justeza Graciela Silvestrii ${ }^{22}$, tomadas en su conjunto, las 665 obras artísticas presentadas al concurso de esculturas -que recordemos se realizó separadamente del concurso de diseño y planificación del parque- decepcionaron. Y esto, podríamos argumentar, tiene su origen al menos en dos factores bien distintos. En primer lugar y en vistas del resultado de la convocatoria, probablemente por un exceso de confianza en la capacidad del arte como objeto de rememoración en el caso particular de la desaparición como objeto del recuerdo ${ }^{23}$. En segundo lugar, porque al separar la reflexión arquitectural de la preocupación artística, la adecuación de cada obra al sitio no siempre fue el resultado de un buen compromiso (imagen 3), hecho que se bosquejaba como una posibilidad en el año 2001 cuando se realizó la primera instalación pero que resulta más que evidente veinte años después de promulgada la Ley 46 con solo 9 esculturas emplazadas y otras 9 que aún esperan poder concretarse ${ }^{24}$.

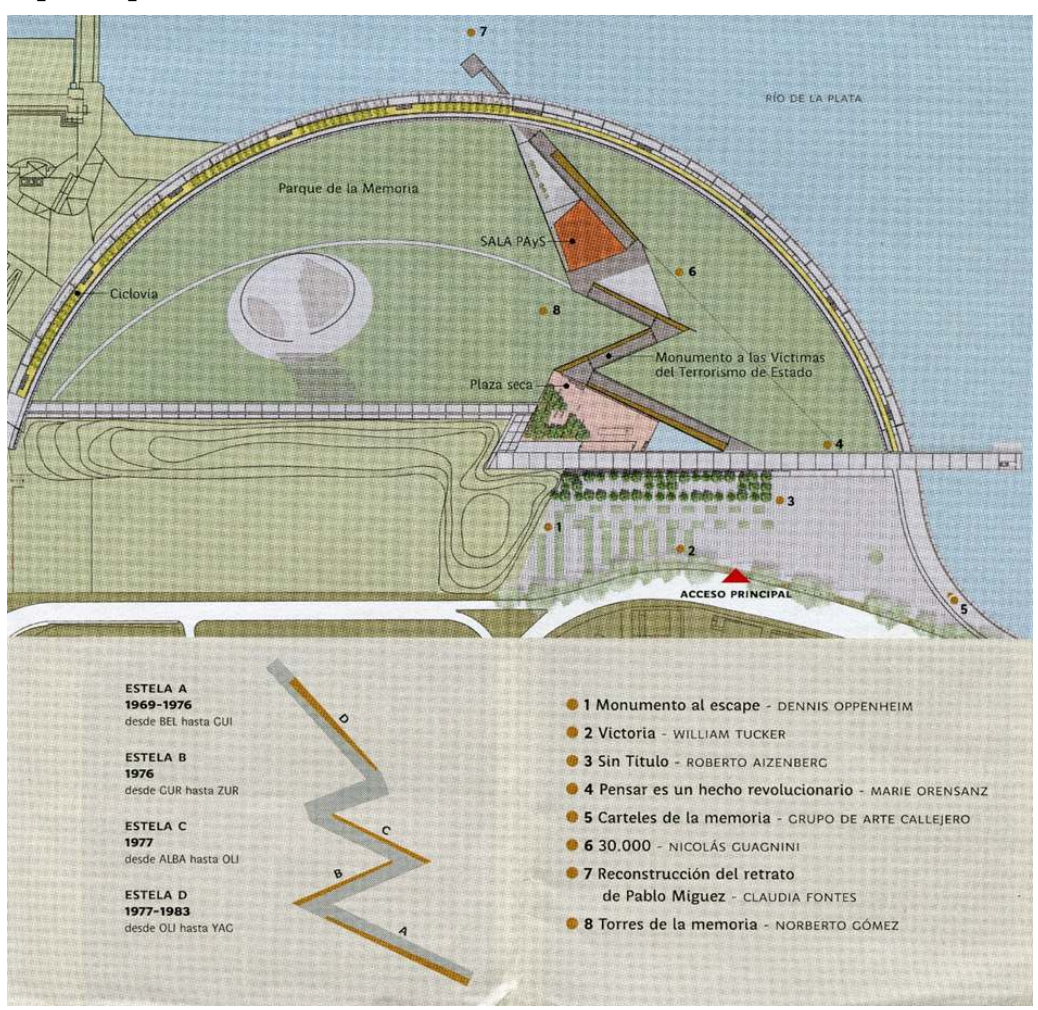

Imagen 3. Parque de la Memoria 25

Dice Silvestri:

Si imaginamos el conjunto del parque con los tres recordatorios, sumándoles las treinta instalaciones elegidas que, de realizarse, probablemente desarmen la contundencia del recorrido original, la forma evoca más un parque temático de la memoria que un memorial, lo que parece bastante lejano de la intención de las organizaciones de derechos humanos que impulsan esta intervención ${ }^{26}$.

Las críticas de Silvestri asimismo que aquellas provenientes de los artistas que decidieron no sumarse al proyecto, con el correr de los años encontraron cierto asidero en la realidad en el sentido en que, hoy en día, el Parque presenta las características de un corpus memorial que no necesariamente coincide con las motivaciones originarias. El MDDHH fundó siempre su memoria en una memoria literal y los rostros de los 
desaparecidos operaron históricamente, a la manera de un espejo, interpelando a cada uno de los que cruzaran sus estáticas miradas. Tan importante es para el MDDHH esta representación de la búsqueda a través de la imagen, que en los primeros años de existencia del Parque de la Memoria la tradicional bandera ${ }^{27}$ con los rostros de cientos y miles de desaparecidos acompañó prácticamente todos los actos que se celebraron en el predio del Parque de la Memoria.

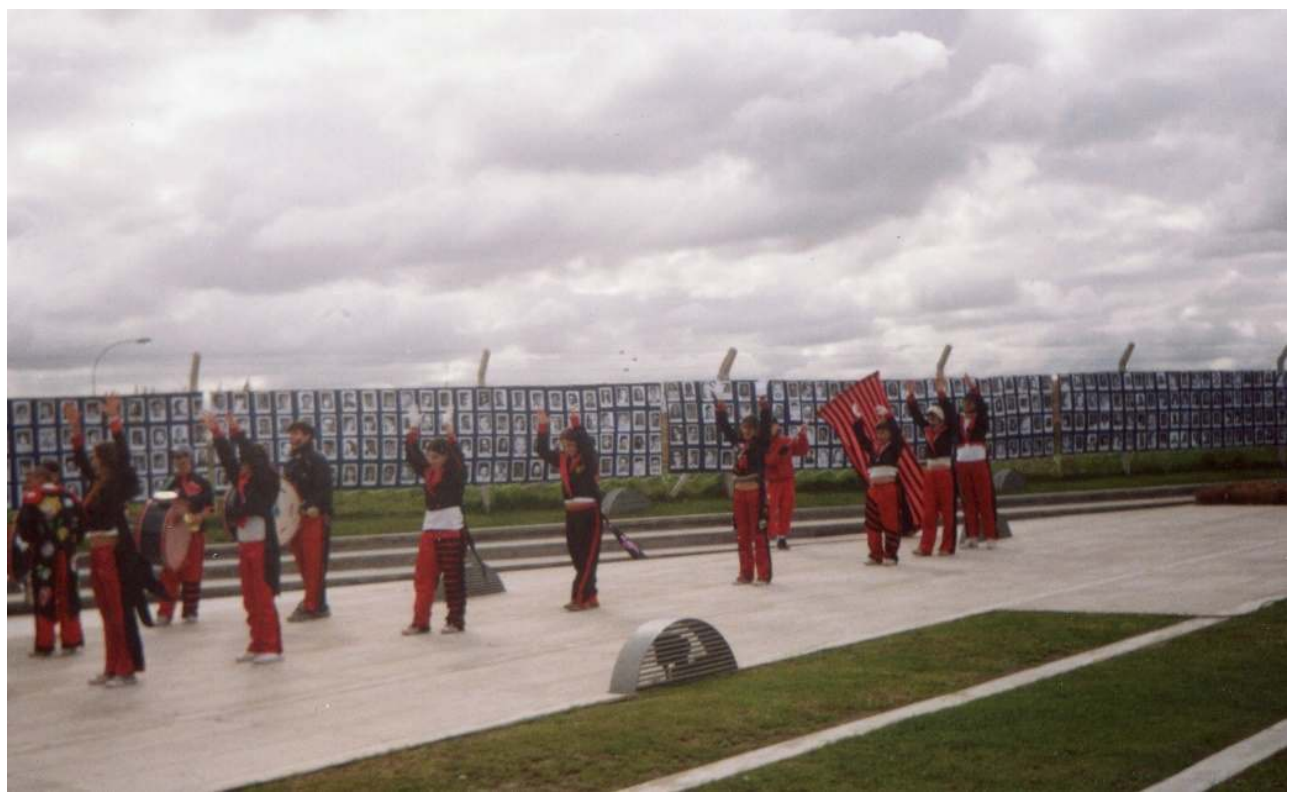

Imagen 4. Acto del dia del Detenido-Desaparecido, 30 de agosto de 2002. Parque de la memoria ${ }^{28}$.

En ese contexto, cada vez que la bandera fue exhibida el efecto producido permitió que las imágenes de las personas que se quería recordar organizaran, desde el punto de vista del sentido, la fragmentación de contenidos emergentes de las obras de arte que tenían como cometido recordarlos, retroalimentándose mutuamente y combinando esa particular memoria literal con otra más abstracta y despojada. Como las ruedas de una bicicleta, desde que la bandera era desplegada y aparecían los rostros de las víctimas, las esculturas eran atraídas hacia ella, como un rayo hacia el centro. Pero al ser esta presencia conmemorativa, por esencia, efímera y ocasional, al cerrarse la bandera e irse del predio el Parque pierde esta especie de polo de atracción que son las caras en blanco y negro recuperando sus contornos permanentes, reduciéndose, por un lado, a las instalaciones artísticas memoriales y, por el otro, al equipamiento edilicio y a las diversas actividades de recreación u ocio propuestas por el municipio. Es decir que la ausencia de referencias literales a los desaparecidos quiebra el proceso de significación ${ }^{29}$ que dio nacimiento al movimiento, estableciendo como permanente, a partir de la elección de obras evocadoras y "desapropiadas", un sistema de diferencias y ambigüedades al cual va a tener que remitirse el observador ávido de respuestas.

La escultura de Fontes, La Reconstrucción del retrato de Pablo Míguez, por su emplazamiento y por devolver su nombre a un desparecido sortea los principales escollos descriptos y junto con la obra 30.000 de Nicolas Guagnini constituye seguramente el sostén más fiel del ideario de la representación de la desaparición buscado por el conjunto de actores intervinientes en la gestión integral del Parque. Seguramente esto es así porque se presenta en contradicción con el absoluto de una conmemoración sin cristalización directa de sentido. La Reconstrucción... trata de encontrar su equilibrio utilizando 
sobriamente la imagen para alejarse de ella y desplazarse al territorio de la interpretación no univoca. Y tal vez lo sea también porque su funcionalidad es precisamente esa: la restitución bucólica de la figura del ausente. Inseparable, in-trasladable del río, La Reconstrucción... es un punto de anclaje memorial para que lo que no puede ser reconstruido a partir de otros lenguajes artísticos encuentre en esta escultura una herramienta para la reflexión. En consecuencia, en una primera aproximación vale preguntarse: ¿cuál es entonces el o los sentidos que esta obra permite concebir desde su primera aprehensión?, ¿qué mensaje transmite La Reconstrucción... justo allí, surgiendo tiesa desde de las entrañas del Plata, allí, entre el cielo y la tierra?

\section{Pablo, desaparecido}

Todavía no son maduros, pero ya no son niños. Aun no tomaron las decisiones fundamentales de

la vida, pero ya están comenzando a trazar sus caminos. No saben mucho de los complejos vericuetos de la política ni han completado su formación cultural. Los guía su sensibilidad. No se resignan ante las imperfecciones de un mundo que han heredado de sus mayores. En algunos aletea el ideal, incipiente rechazo de la injusticia y la

hipocresía que a veces anatematizaron en forma tan enfática como ingenua. Quizás porque viven en sus propios cuerpos vertiginosos cambios, recelan de cuanto se les presenta como inmutable. Casi 250 chicas y chicos que tenían entre 13 y 18 años desaparecieron, siendo secuestrados en sus hogares, en la vía pública o a la salida de los colegios [...].

Comisión Nacional sobre la Desaparición de Personas ${ }^{30}$

muchos otros artistas, en el marco de las fervientes discusiones públicas -que enunciamos anteriormente- sobre la pertinencia de participar desde el arte de este tipo de homenajes, según lo da a entender en algunas entrevistas de la época, Claudia Fontes vaciló antes de enviar su obra al concurso. Probablemente -especulamos- por la trascendencia y la novedad del desafío que en su doble movimiento político y artístico exigía de los concursantes una creatividad destinada a traspasar sus límites para institucionalizarse como herramienta de las memorias. Se les pedía a los artistas que, sin dejar de hacer arte, es decir, sin dejar de romper con lo establecido, sin dejar de revolucionar el statu quo, borraran las fronteras temporales entre la entidad a recordar y el porvenir impidiendo igualmente que la re-presentación de la cosa significada omitiera la historia de aquello que se sugiere recordar. La obra debía ser una herramienta pedagógica capaz de establecer canales de comunicación entre los diferentes "hoy" y las consecuencias más aberrantes del terrorismo de estado. Ahora bien, ¿qué se le exige al arte cuando se le confía la representación de lo irrepresentable por ser este desconocido? ¿Cuál es la naturaleza de "lo" desconocido? ¿La desaparición, la muerte? ¿Lo ininteligible de la experiencia del "otro" que no puede ser narrado? Y, en vistas a la transmisión 
presente y futura, ¿la complejidad de la naturaleza del "otro" puede ser remplazada por los emblemas de la resistencia de los familiares? ¿Debe el artista abocarse a una representación literal de la simbología presente en la búsqueda de los desaparecidos? 0 , por el contrario, ¿debe proponer una representación abierta, aun corriendo el riesgo de la incomprensión? ¿Representación de lo humano, de lo inhumano? ¿Del hecho (crimen)?, ¿de la resistencia al crimen?, ¿del trastorno y del quiebre social que provoca el crimen? Y el Río, ¿debe intervenir como un río cómplice o como un río redentor? ¿Testigo? ¿Actor? ¿Qué poiesis para cual praxis? ¿Qué hacer aparecer, qué presentar, qué producir como recuerdo? Al asumir el reto de dar una respuesta a estos problemas estéticos-políticos y re-imaginar cómo era el desparecido Pablo Míguez Márquez, la artista concibió su proyecto eligiendo una individualización diáfana, perceptible, individual, y simultáneamente colectiva, concreta y paradójicamente compleja, contradictoria y discutible. "Mi proyecto -dice Fontes- es nominal, explicito, particular, figurativo, descriptivo, personalizado, oportuno y puntual, fechado, anclado a una hora y lugar, y es en ese metro cuadrado de río donde puede adquirir significado" ${ }^{31}$.

31 La escultura La Reconstrucción del retrato de Pablo Míguez de Claudia Fontes, homenajea uno de esos 250 chicos y chicas adolescentes detenidos-desaparecidos y en ese uno "nominal, particular y personalizado", refleja la historia de todos y cada uno de los otros $249^{32}$ que no volvieron de los campos. ¿Por qué Pablo y no el Negrito Avellaneda o Aida Victoria Porta? ¿Quién era Pablo?

\section{Pablo y Lila}

32 El caso de Pablo Míguez fue expuesto públicamente a la salida de la dictadura y retenido como prueba para enjuiciar primero a los comandantes de las juntas militares $y$, posteriormente, a los restantes implicados en la megacausa ESMA ${ }^{33}$, uno de los centros clandestinos de detención tortura y exterminio donde el joven estuvo secuestrado y en el cual fue visto por otros compañeros de infortunio, entre ellos Lila Pastoriza, sobreviviente:

-Entre los detenidos de esa época había un chico que se llamaba Pablo, que era un chico de 13 años creo... que había estado previamente en un lugar que, según él me dice, estaba ubicado en las inmediaciones de Camino de Cintura y Richieri...

- ¿Esto se lo dijo el chico Pablo?

-El chico, sí, Pablo. A Pablo lo traen una tarde de agosto. Yo escucho un guardia que le dice a otro... los guardias eran muchachos muy jóvenes, también llamados ahí verdes. Un guardia le dice al otro: "Mira a lo que hemos llegado" mientras que le levanta la capucha. Yo no sabía que era un chico y lo instalan en la cucheta al lado mío. Pablo se pega mucho a mí. Era un chico muy chico... ${ }^{34}$.

Como lo dijimos al comienzo, Pablo fue secuestrado con su madre. Primero fue llevado detenido al Campo "el Vesubio". Allí permaneció tres meses, soportando cruentas torturas. Luego fue transferido solo a la Escuela de Mecánica de la Armada y se lo vio con vida por última vez en la comisaria de Valentín Alsina. Era el mes de octubre de 1977 y ya habían pasado 5 meses desde el inicio de su martirio. 


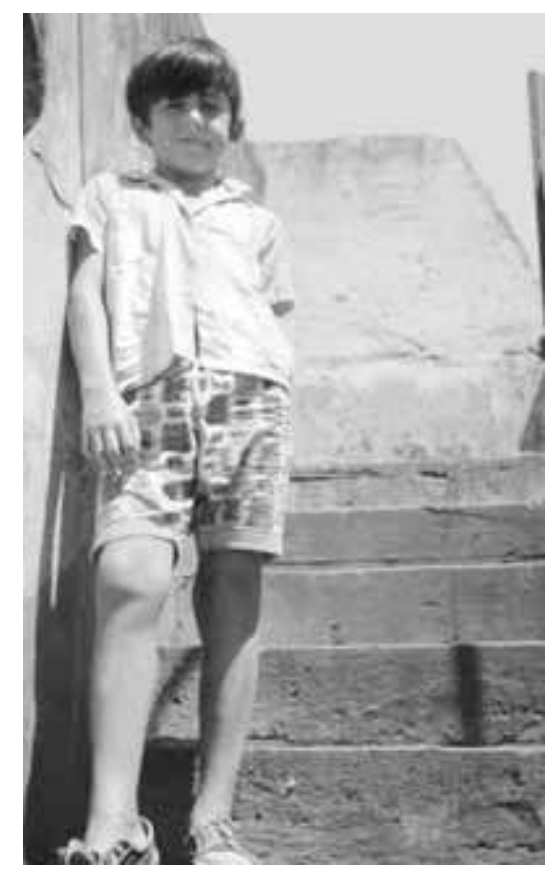

Imagen 5. Pablo Míguez ${ }^{35}$

Veinte años más tarde, el 24 de marzo de 1998, Pastoriza publica en el diario Página 12 la historia del joven y cuenta aquella partecita vivida en común. El título era elocuente y acusador: "No se sabía qué hacer con él". El subtítulo lo identificaba como una víctima especial: "La historia de Pablo Míguez, desaparecido de la ESMA cuando tenía catorce años". Esta nota, que fue la tapa del día conmemorativo del 22 aniversario del golpe de Estado cívico militar, narraba detalladamente el desgraciado recorrido del joven por los tres campos en los cuales estuvo detenido a partir de las voces testimoniales de los sobrevivientes. Por lo monstruoso de lo allí descrito, el artículo se sumergió imperceptiblemente en la memoria de los lectores para traer desde lo más profundo de ella una categoría de víctimas del terrorismo de Estado que parecía olvidada o que, al menos, no tenía por ese entonces la visibilidad social que le imprime al crimen el agravante de que la víctima sea menor de edad y que su cuerpo fuera utilizado por el torturador como una herramienta extorsiva-represiva hasta perder utilidad a los ojos del represor $^{36}$. Para que esto fuera posible, los recuerdos de Pastoriza tuvieron que desplazarse de la esfera borrosa de la intimidad para hacerse netos y encontrar un espacio de recepción mediático.

Para que Pablo tomara dimensión pública, Lila Pastoriza forzó el recuerdo, el propio y el social. Pastoriza fue testigo de Pablo, de su vida y de su des-existencia: reunidos en el sector llamado "capuchita", los dos secuestrados se protegieron mutuamente, hablaron, se confiaron el uno al otro. Pablo quería que lo llevaran con su papá y esa esperanza compartida por Lila- lo sostuvo durante el encierro.

-Él se despertaba a la noche llamando a su madre y entonces se arrodillaba frente al tabique. Yo siempre hacia lo mismo, es decir: lo acariciaba un poco...Inauguro una nueva manera de comunicarse en capucha, que estaba prohibido hacer eso, que era arrodillarse frente al tabique de las cuchas...

- ¿Qué fue luego de este chico Pablo?

-Un día, no estoy muy segura, pero creo que fue a fines de septiembre, cuando volvía del baño, veo a través del... Bueno, yo volvía con lo que nos ponían en los ojos -que ahí le llamaban tabique, que era una especie de antifaz y que yo lo tenía medio 
levantado-, veo que a Pablo se lo llevan de la mano uno de los Pedros, que eran los jefes de guardia, y cuando llego a mi cucheta y voy al cuartito me entero que acababa de haber un traslado. Me resultó muy extraño porque en general cuando había traslado, había muchas medidas de seguridad y nadie podía estar en el baño. Cuando vinieron a buscarlo a Pablo pregunto por mí y... Bueno, se lo llevaron. Y vi que se habían llevado a otra gente más, no solo a él, a tres o cuatro más. De todos modos, como había sido un traslado así, yo siempre tuve la esperanza de que lo hubieran llevado a su casa (Lila, visiblemente emocionada, se agarra con fuerza de los brazos de su asiento) pero no he tenido noticias de él. ${ }^{37}$

Cuando lo vio partir, Lila Pastoriza, no sabía a ciencia cierta cuál era el apellido de Pablo ni a dónde lo llevaban. Recién pudo asociar un nombre a la imagen al obtener la confirmación de su desaparición en 1985, cuando, a la salida de la Cámara Federal, luego de haber declarado en el juicio contra las juntas militares, alguien de la asistencia le entrega un volante con la foto de Pablo y el texto: Pablo Míguez, desaparecido. Pastoriza, hizo de esta historia su "deber de memoria". Se entrevistó con Juan Carlos Míguez, el padre, con otros sobrevivientes como ella y con el Equipo Argentino de Antropólogos Forenses. Pasaron años, varios, hasta que el conjunto de piezas hilvanadas con cuidadosa paciencia fuera publicado por Página 12 y así el relato se socializara ${ }^{38}$. Este artículo fue vital para reposicionar los fragmentos de la historia de todos los intervinientes en ella, incluida aquella parte de la sociedad que decidió dejar de ser espectadora. En este último grupo se encontraba Claudia Fontes.

\section{De Lila a La Reconstrucción...}

La exposición pública del caso puede ser tomado como un principio de explicación de porqué Claudia Fontes eligió a Pablo como imagen referente. También ha expresado la artista que fue importante en esta elección el hecho de que cuando se confrontó con esta historia tomó conciencia que ambos, Pablo y ella, tenían la misma edad. Fontes recurrió a prácticamente todas las fuentes utilizadas por Pastoriza e incorporo otras propias: observo fotografías, escucho historias y trabajó con jóvenes adolescentes. Todo ello con el objetivo de ser fiel a la imagen de Pablo en vida. Imaginó su cara, su andar y cómo sería su "estar quieto", en eterno balanceo fluvial .... 


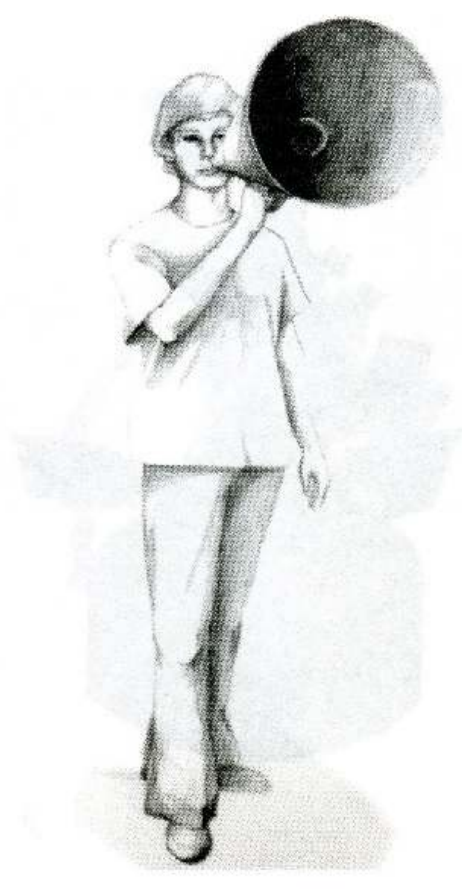

Imagen 6. Bocetos de la obra, ganador del Concurso de Esculturas ${ }^{39}$ recién en 2010. Su ubicación, a pocos pasos del Monumento a las Víctimas del terrorismo de Estado, inaugurado tres años antes, le permite también ser vista sin obstáculos desde la sala poli actividades PAyS (Presentes ahora y siempre) ${ }^{42}$ lugar en el cual se realizan manifestaciones culturales y pedagógicas involucrando particularmente a jóvenes adolescentes. Si comparamos el proyecto original con el resultado obtenido, vemos que algunas modificaciones fueron incorporadas: en la escultura definitiva se abandona la idea del megáfono que daba al aparecer de Pablo la expresión de un cierto dinamismo y rebeldía. La imagen de un joven con un megáfono en la mano es la de un joven actor comprometido con su presente, que comunica sus ideas a otros tratando de provocar una respuesta. Y si esta imagen es cierta en la Argentina de hoy -basta sólo pensar en la participación juvenil en las manifestaciones por la ley de aborto legal y seguro- mucho más lo fue en la Argentina de los años 60 y 70. Otra diferencia con el proyecto original es la cercanía de la escultura con el espectador. En el proyecto ganador, Pablo avanzaba hacia las aguas, desafiante, y su rostro no iba a ser completamente perceptible a 30 metros de la orilla; podía llegar a vislumbrarse desde algunos ángulos. Hoy La Reconstrucción... mira, de espaldas a la orilla, hacia el horizonte, 40 metros más allá de la 
posición prevista. Desde la plataforma-observatorio, al igual que desde los amplios ventanales de la sala PAyS, se vislumbra la imagen de Pablo a lo lejos, un brazo extendido a lo largo del cuerpo y el otro cruzando la espalda a la altura de la cintura. Un gesto de espera y de andar, de estar y de entrar en las aguas. ¿Ingenuo? ¿Dócil? ¿Inocente? ¿Quiso Fontes decirle a la sociedad que el terrorismo de Estado fue particularmente cruento porque actuó sobre víctimas inocentes? ¿Tomó partido por re-presentar el ausente y en consecuencia a los 250 (o más) jóvenes ausentes, como seres apolíticos? Sabemos que muchos adolescentes fueron desaparecidos de sus lugares de militancia barriales o a causa de sus militancias en centros de estudiantes. ¿No son estos ejemplos válidos para una política pública que quiere arrogarse el status de una memoria "perenne"? Para construir una memoria oficial, ¿hace falta un arquetipo no conflictivo en el cual se pueda identificar la mayor parte de la sociedad? ¿Es Pablo ese ejemplo?
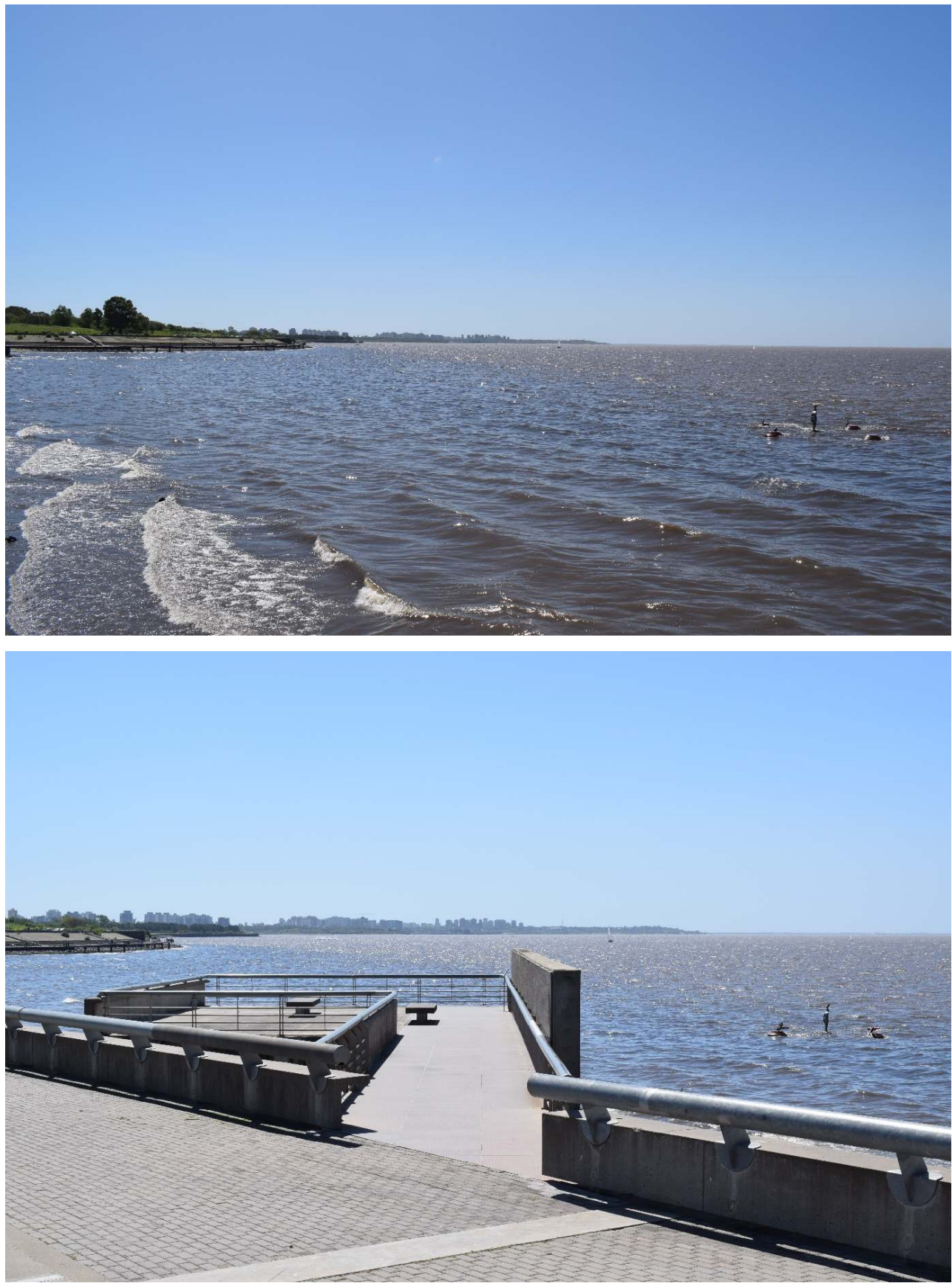


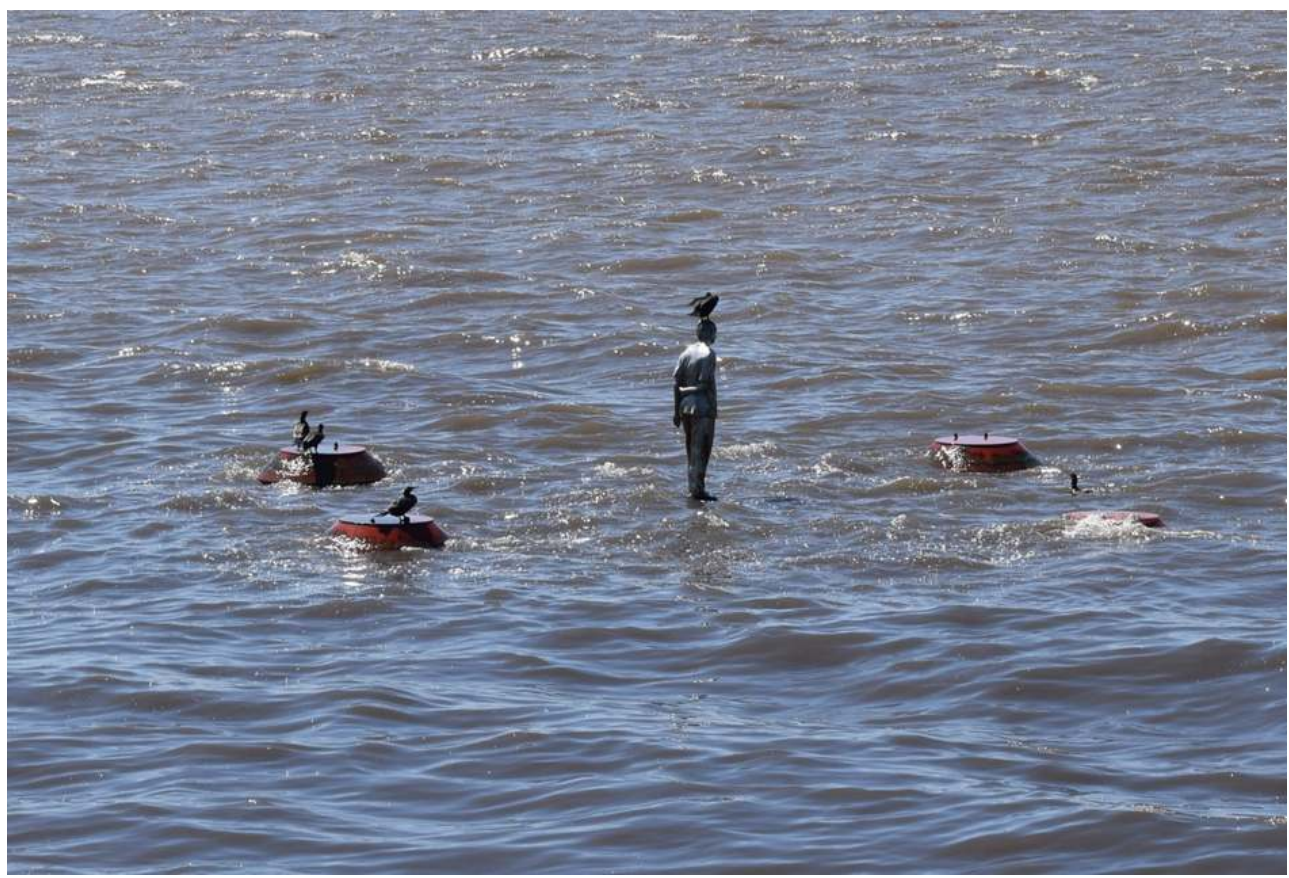

Imágenes 7 a 9. Claudia Fontes, La Reconstrucción del retrato de Pablo Míguez ${ }^{43}$

Como lo muestran las imágenes 7 a 9, a simple vista Pablo es inaccesible. La "ausencia" del rostro que se sabe existe, pero es inalcanzable, invisible, no permite que pueda diferenciarse a quien pertenece ni su fidelidad al modelo original, fuente política y estética de inspiración. Solo se produce la identificación gracias al cartel previsto para eso, que lo enuncia y nos anticipa el quien, el cuándo y su creador. Nuevamente surge la pregunta: ¿Por qué Pablo Míguez?

\section{Dice Fontes:}

[...] anhelo que al recordar que el día 12 de mayo de 1977 a las tres de la mañana Pablo Míguez, de 14 años de edad, fue privado de su libertad y de su futuro, se mantenga en pie la verdad irreductible de que por lo menos esta tremenda injusticia sí tuvo y sigue teniendo lugar. Participo porque quisiera que nadie se atreva a desvirtuarlo. ${ }^{44}$ 


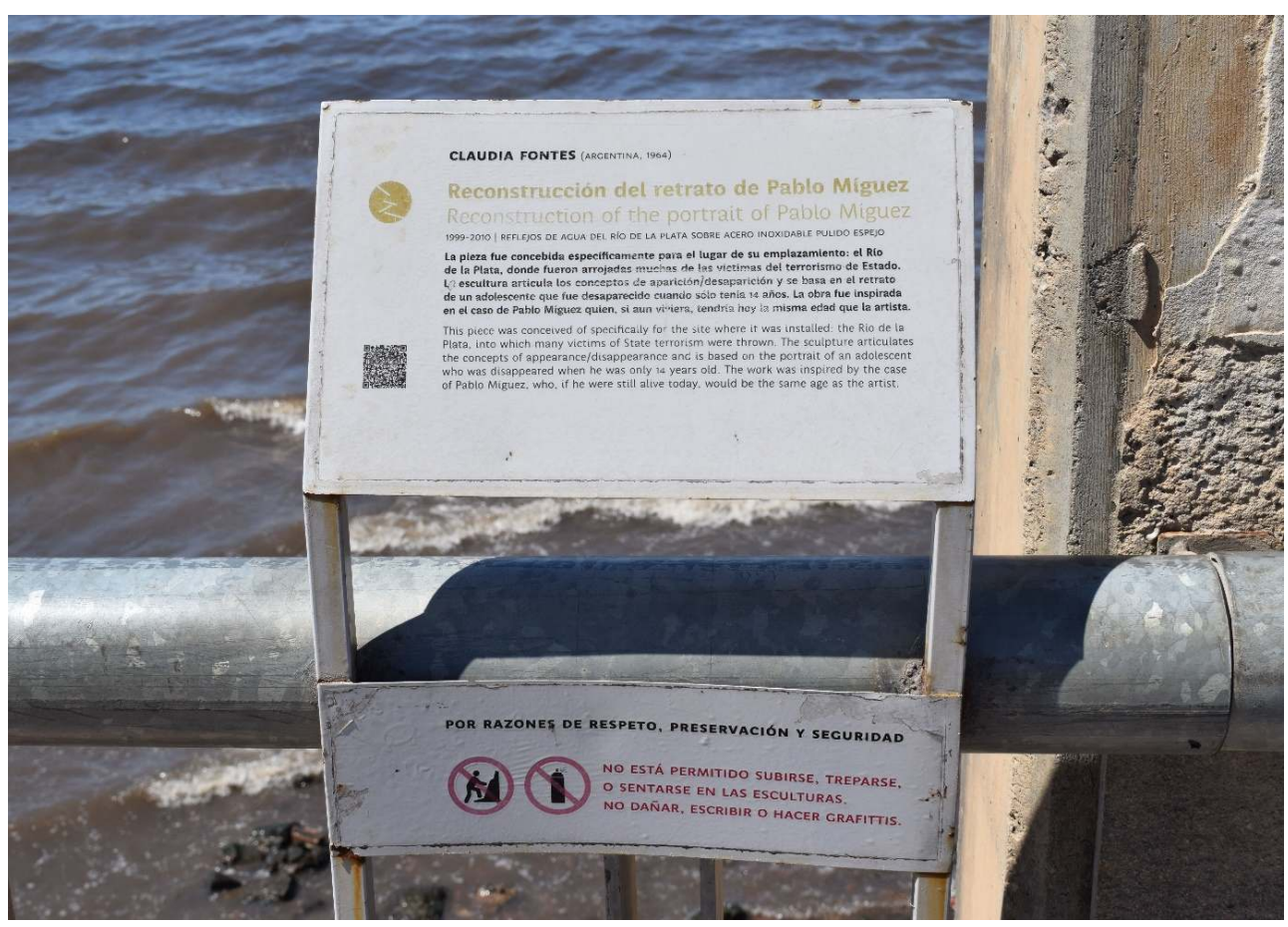

Imagen 10: Placa45.

\section{Y, ¿por qué el Río de la Plata por morada?}

El río tiene la historia que tiene que es terrible y que tiene que ver con los cuerpos que posiblemente -incluso el caso de Pablo Míguez- terminaron en ese río" ${ }^{46}$.

La Reconstrucción... se alza y levanta su entidad de objeto pretendiendo equivalencia con "la verdad irreductible" del secuestro y de la desaparición. Reproduce una última imagen, aquella que quedó registrada en la retina de Lila Pastoriza cuando se "lo llevaban", cuando lo "trasladaban" de la ESMA a la comisaria de Valentín Alsina. La fuerza de este irse hacia las aguas reduce el adolescente a un imaginario particular: su cuerpo debe estar en el río, allí va, allí hay que recordarlo. Nada en su posición erguida, pero pasiva, casi resignada, nos remite al joven vivaz y pícaro que en cautiverio daba aliento a los otros, tal como lo describen sus compañeros detenidos. No hay en esta propuesta un emergente de la resistencia como contrapoder en los campos, menos aun de la vida de un joven hijo de una madre militante. Al re-presentar a los otros, deja de ser él. Es imagen inacabada, silencio. Pablo es traído al río artificialmente y con su aparecer lo embebe de la pureza del inocente. Enlaza la tierra, la lleva consigo y con ella la vida, se despide y entra al Río. Pablo está en el río, corporifica cada uno de los nombres escritos en la piedra gris del Monumento. Al ritmo de la marea, esta escultura, se agita y agita, se debate y cuestiona en su balanceo el estatus del desaparecido, aquel que el dictador alguna vez quiso definir como "ni muerto, ni vivo", aquel que lo sitúa en una especie de limbo para ser aprendido y poder reposar. 


\section{Pablo y los pescadores}

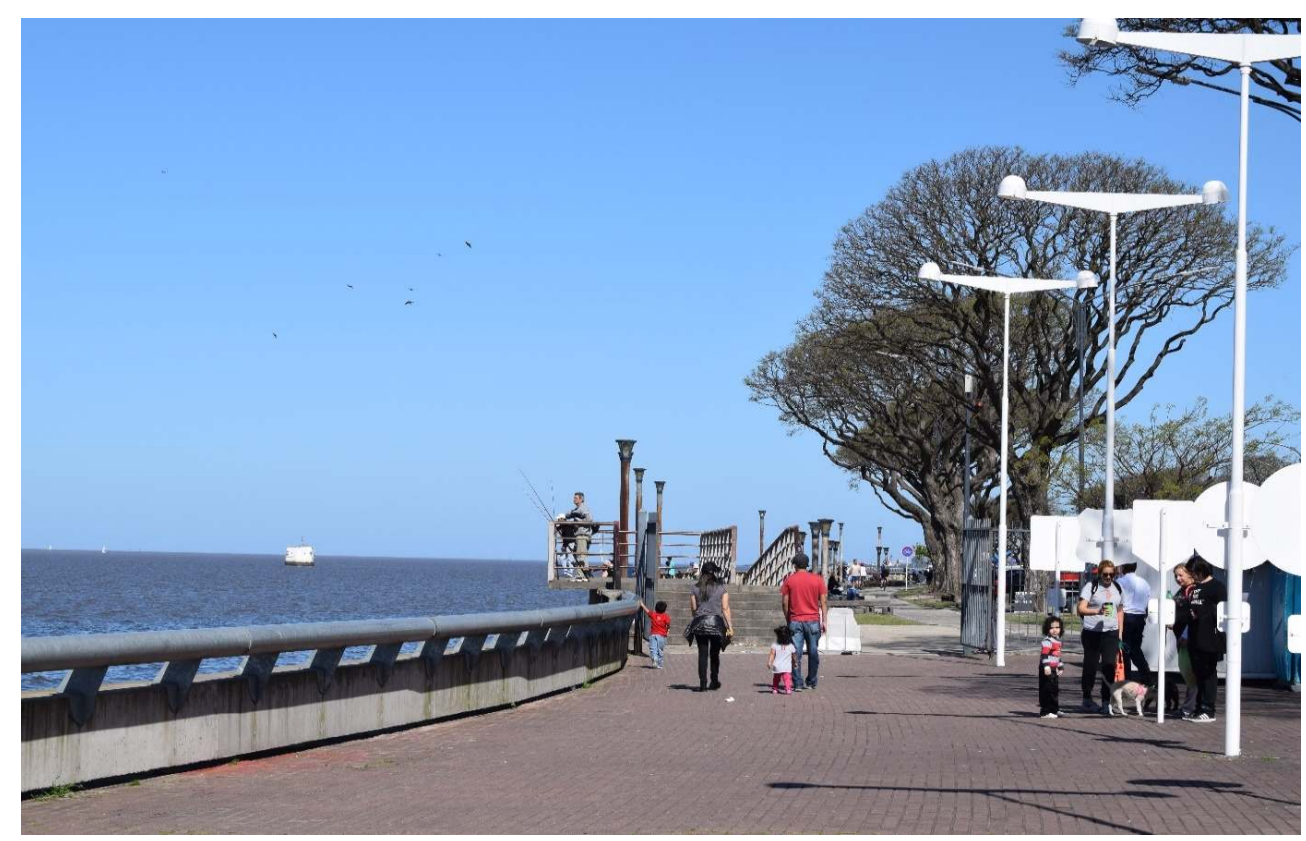

Imagen 10. Paseo de los pescadores ${ }^{47}$

A la entrada del Parque, que se realiza habitualmente por el costado y no por la entrada central, generando que los paseantes ingresen naturalmente casi sin saber de qué tipo de espacio se trata, la silueta lejana, de contornos difusos e imprecisos, contrasta con la prolijidad del paseo dominical y oficia de punto de intersección entre el abismo de los campos de la muerte y el Río. El observador, los observadores, difícilmente conozcan los hechos que dispararon la atención de la autora, desplazándose desde el imaginario de la desaparición en general hasta la vida de Pablo en particular, y seguramente no sepan quiénes son los que continúan activando su memoria y quiénes batallaron porque ese espacio memorial exista. Algunos quizás transmuten del paseo de los pescadores que lo ladea hacia el Parque de la memoria sin prestar atención alguna, apropiándose naturalmente de los amplios espacios verdes para pasar un momento en familia o entre amigos, ignorando involuntariamente la finalidad específica de ese parque de esculturas. El visitante del domingo no es necesariamente el familiar que ingresa con pañuelos y flores. Entonces, ¿cuál es el punto de encuentro entre el visitante y Pablo Míguez, entre ese paseante dominguero parcialmente informado y la entidad que la obra resignifica? ¿Qué transmisión es posible? Fontes asegura que produce para que no se olvide. Su voluntad, dice, es "hacer justicia", impidiendo que el recuerdo se desvirtúe y se borre con el tiempo, pero paradójicamente no es justicia para Pablo la que se logra, en todo caso no lo es con el "caso" Pablo Míguez. No produce los efectos del artículo de Pastoriza ${ }^{48}$, ni el del fallo del Tribunal Oral Federal. La justicia que pretende Fontes tiene otros contornos y otra dinámica hacia el futuro. La materialidad que ofrece La Reconstrucción... al observador desprevenido no estabiliza el soporte físico del recuerdo en la figura de Pablo, el ausente. Como aquel que no ha vuelto, su representación es inabordable, indescriptible, inaprensible. No puede haber recuerdo. Pablo Míguez Marques es el objeto de lo imposible de recordar a través de nuestras memorias. Aparece como un fantasma, un espectro, un símbolo. Reconstrucción material de la ausencia de materialidad. Porque la 
estatua de Míguez está ahí es que podemos decir que Pablo no está, que Pablo Míguez Marques sigue desaparecido. El que mira se confronta con un universal, un ideal de la desaparición, al que completa con un particular que le es afectiva y sensorialmente propio. Sutura la falla con sus propios recuerdos. Y confrontado al reflejo de la escultura sólo le quedan dos caminos: o querer ver el todo más allá de lo que efectivamente quiere enunciar la obra -icono del horror- o rechazarla otorgándole el estatus de una escultura más entre las otras ${ }^{49}$. Y es este ciertamente uno de los problemas cruciales de la institucionalización de la memoria en este tipo de espacios.

\section{Reflexiones...}

El Parque de la Memoria-Monumento a las Víctimas de Terrorismo de estado es un lugar de recuerdo y de testimonio, porque allí están los nombres de esos seres a los que se quiso borrar. Ellos estarán presentes en la evocación que se haga de sus vidas truncadas y en el permanente homenaje a los ideales de libertad, solidaridad y justicia por los que vinieron y lucharon. Las generaciones actuales y futuras que lo visiten que se enfrentaran allí con la memoria del horro cometido y tomaran conciencia de la necesidad de velar por que NUNCA MAS se repitan estos hechos" Comisión Pro-Monumento a las Víctimas del Terrorismo de Estado ${ }^{50}$

La desaparición es una práctica sistemática colectiva, querida, planificada tanto en su ejecución como en el ocultamiento de sus rastros. Los desaparecidos, su representación, es también una construcción colectiva. No hay memoria sin otro. No hay memoria sin una base social de significación. La construcción narrativa de la memoria es múltiple y conflictiva, en mutación constante y reactivada siempre desde el presente de aquel que recuerda o se obliga a recordar. La memoria es inoponible al olvido puesto que entrelazados ambos forman parte constitutiva del otro. En suma, la narrativa de la memoria no existe como tal. Un Parque de la memoria, no puede ser más que la muestra de esa lucha por imponer una por sobre las otras y a esta se le asigna carácter de memoria oficial.

La imagen, el rostro, el nombre, del desaparecido y asesinado fueron el eje memorial del recuerdo individual y de las acciones colectivas del MDDHH. En la configuración del parque poliescultural, el rostro de Pablo, enunciado, y de existencia vedada, es apropiado por el río. Único espectador "completo", es el único en poder dar cuentas de la veracidad del pensamiento como recuerdo. Así, por fuera del marco que le puede dar la acción memorial explicativa, la instalación permanente de la estatua nos ofrece una gramática ligada casi exclusivamente a la lectura que pueda hacerse del río. El río y La Reconstrucción del retrato de Pablo Míguez son inseparables. Juntos conforman una posible memoria de la desaparición que se articula a su vez con la metáfora de la herida. Metáfora no necesariamente feliz puesto que la herida deja cicatrices, pero sutura y se cierra. $Y$ en este caso, la herida en la tierra se clausura con el monumento y la nómina de nombres. El monumento-lapida-tumba concluye la búsqueda y silencia la responsabilidad. Dice Patricia Tappata de Valdez, de la Comisión pro-Monumento y directora de Memoria Abierta, en esa época:

El río de la Plata puede ser ahora reconocido como "sitio histórico" y allí se concentran los familiares de las víctimas para recordarlas y poner flores en el lugar que se convirtió en la tumba de muchos. ${ }^{51}$

Al concebir una acción memorial como monumental, se fija en el tiempo y en el espacio una estrategia para el recordar. Al mismo tiempo el MDDHH subsume parte de sus 
variables identitarias a la acción del actor político. Y esto es porque la gramática de sentido monumento-lapida-tumba asociado al río-tumba presentada como memoria oficial permite, que, aun cambiando de gobierno, el parque como política pública se coloque a disposición de una utilización irresponsable de la memoria de la desaparición. Irresponsable como sinónimo de duelo y no de reclamo de justicia. Al menos así quedó establecido cuando el 24 de marzo de 2016 el actual presidente de la Nación, Mauricio Macri condujo al ex presidente de los Estados Unidos, Barack Obama a las orillas del río y juntos le arrojaron flores blancas en honor a los desaparecidos.

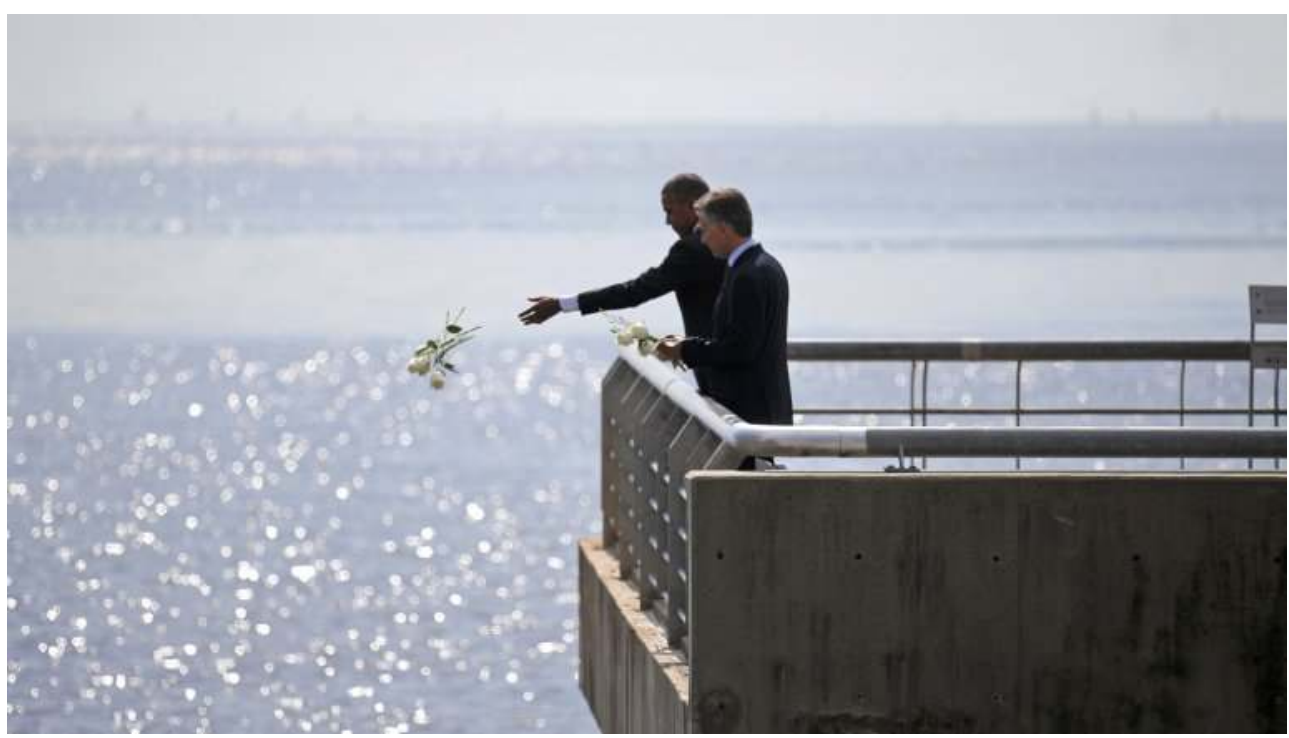

Imagen 11. Mauricio Macri y Barack Obama: homenaje a los desaparecidos ${ }^{52}$

La ciudad y su río participan de la producción de sus memorias y establecen contenidos locales de alcance nacional e internacional. De un lado el río es el espacio de la ciudad viva, de los pescadores, los estudiantes y las familias. Del otro, se transforma en el espacio del recuerdo familiar de "los desaparecidos-muertos". Dos sociedades, múltiples memorias y un solo río. En ese confluir, la presencia de la escultura que rememora a Pablo remite por cierto al río como potencial soporte cadavérico, pero otra comprensión de esta presencia es imaginable: La Reconstrucción... le recuerda al Río de la Plata que es memoria y no olvido. El Río de la Plata inició el camino memorial en el mismo momento en que, como un grito silencioso, devolvió algunos de los cuerpos que le fueron arrojados. Nos dijo: aquí están las pruebas. Nos mostró el sentido de la responsabilidad indicando que hubo crímenes y exigiendo que se investigue. Obligando a los Scilingo que reconozcan su participación. Cuando en sus aguas aparecieron lo que se quería hacer desaparecer, cuando quebró la impunidad de la falta de huellas con las fuerzas de Neptuno, el río dislocó la estrategia del silencio y dijo SOY MEMORIA DE LA DESAPARICION. 


\section{BIBLIOGRAFÍA}

Asociación Madres de Plaza de Mayo, Historia de las Madres, Buenos Aires, Ediciones Madres de Plaza de Mayo, 1999.

Civale Cristina, “Arte y política en la bienal de San Pablo”, en revista Asterisco, Año 4, n 184 , septiembre de 2010, Buenos Aires.

Comisión Pro-Monumento a las Víctimas del Terrorismo de Estado, Escultura y Memoria, Buenos aires, Eudeba, 2000.

Comisión Pro-Monumento a las Víctimas del Terrorismo de Estado, Proyecto Parque de la Memoria, Escultura y Memoria, Buenos Aires, Gobierno de Buenos Aires / Comisión Monumento a las Víctimas del Terrorismo de Estado, Buenos Aires, 2003.

Comisión Nacional sobre la Desaparición de Personas, CONADEP, Nunca Más, Buenos Aires, Eudeba, 1985 y reediciones.

Dandan Alejandra, "No se sabe nada de lo que pasó con Pablo", en diario Página 12, 11 de octubre de 2010, Buenos Aires.

Deleuze Gilles, Diferencia y repetición, trad. de María Silvia Delpy y Hugo Beccacece, Buenos Aires, Amorrortu. 2002.

Deotte Jean-Louis, "Las paradojas del acontecimiento de una desaparición”, en Raynald Belay, Jorge Bracamonte, Carlos Iván Degregori y Jean Joinville Vacher (ed.), Memorias en conflicto, Lima, Institut français d'études andines, Instituto de Estudios Peruanos, Embajada de Francia en el Perú, Red para el Desarrollo de las Ciencias Sociales en el Perú, Lima, 2004.

Didi-Huberman Georges, Images malgré tout, París, Les Editions de Minuit, 2003.

Espacio Memoria, Cuadernos de la Memoria 1. Leyes. Principales instrumentos legales sobre derechos humanos y memoria, Buenos Aires, Instituto espacio para la Memoria, 2009.

Falletto Verne Enzo, "Propuestas para el cambio. Movimientos sociales en la democracia", en Nueva Sociedad, n 91, Venezuela, septiembre-octubre 1987, p. 141-147.

Ginzberg Victoria, "El Parque de la Memoria, un lugar frente al río" en diario Página 12, 31 de agosto de 2001, Buenos Aires, p. 14.

--, "La hora del desencuentro”, en diario Página 12, 26 de marzo de 1999, Buenos Aires.

Hochbaum Nora y Battini Florencia (coord.), Monumento a las víctimas del terrorismo de Estado. Parque de la memoria, Buenos Aires, Consejo de gestión de Parque de la memoria/Gobierno de la Ciudad Autónoma de Buenos Aires, 2010.

Huyssen Andreas, "El Parque de la memoria. Una glosa desde lejos", en revista Punto de Vista n 68, diciembre del año 2000, Buenos Aires.

Insua Myrna, Où sont les disparus? H.I.J.O.S. et HIJOS, Identité et Action Collective. Une étude de cas á partir des théories des Mouvements Sociaux, Mémoire du Diplôme d'Études Approfondies, discipline sociologie, École des Hautes Études en Sciences Sociales-Paris, 2001.

Laclau Ernesto, Emancipación y diferencia, Buenos Aires, Ariel, 1996. 
Malosetti Costa Laura, "La polémica por los monumentos de la memoria", en revista Ñ diario Clarín, 24 de julio de 2004, Buenos Aires.

Melucci Alberto, “Asumir un compromiso: identidad y movilización en los movimientos sociales”, en Marisa Revilla (comp.), Zona Abierta 69. Movimientos Sociales, Acción e Identidad, Madrid, 1994, p. 153-180.

Nora Pierre, "Entre Mémoire et Histoire", en Pierre Nora (ed.), Les lieux de mémoire, vol. 1 (La République), París, Gallimard, 1997.

Pastoriza Lila, "No se sabía qué hacer con él. La historia de Pablo Míguez, desaparecido de la ESMA cuando tenía catorce años”, en diario Página 12, 24 de marzo de 1998, Buenos Aires, p. 5.

Silvestri Graciela, “El arte en los límites de la representación”, en revista Punto de Vista, n 68, diciembre del año 2000, Buenos Aires.

--, "Memoria y monumento" en revista Punto de Vista n64, agosto de 1999, Buenos Aires.

Sin Firma, "Claudia Fontes: La labor de los artistas es inventar maneras de entender el mundo", en diario El Tribuno, Salta, 7 de octubre 2016.

Tappata de Valdez Patricia, "El Parque de la memoria en Buenos Aires" en Elisabeth Jelin y Victoria Langland (comps.), Monumentos, memoriales y marcas territoriales, Madrid, Siglo XXI, 2003.

Vásquez Inés, "El monumento y el río", en Diario de las Madres de Plaza de Mayo, Año XV, n¹62, abril de 1999, Buenos Aires, p. 11.

Verbistky Horacio, El vuelo, trad. Anatole Muchnik, París, Ed Dagorno, 1995.

VV. AA, Arquitectura y memoria, Buenos Aires, Memoria Abierta, 2009.

Documentos y Leyes

Asociación Madres de Plaza de Mayo, Carta abierta a la opinión pública, marzo de 1999, mimeo, archivo personal.

Asociación Madres de Plaza de Mayo, Nuestras consignas (actuales), Folleto, Buenos Aires, 1999, archivo personal.

C.E.L.S, Adolescentes detenidos desaparecido, Folleto, Buenos Aires, 1982, archivo personal.

Comisión Pro-Monumento a las Víctimas del Terrorismo de Estado, Bases y reglamento del Concurso de esculturas del Parque de la Memoria, 1999, archivo personal.

Comisión Pro-monumento a las víctimas del Terrorismo de Estado, Documento leído en el acto de colocación de la piedra fundamental del Monumento a las víctimas del Terrorismo de Estado, Buenos Aires, 24 de marzo de 1999, mimeo, archivo personal.

Ley n 46 de la Ciudad de Buenos Aires, "Parque de la Memoria”, Sancionada el 21de julio de 1998, promulgada de hecho el 14 de agosto de 1998. BOCBA N 514 del 25/08/1998. Derogada parcialmente por la Cláusula Transitoria 1ํ de la Ley nº 3.078, BOCBA nº 3215 del 15 de julio de 2009.

Ley n⿳0 3.078 de la Ciudad de Buenos Aires, creación del “Consejo de gestión del Parque de la memoria y del Monumento a las Víctimas del Terrorismo de Estado" sancionada el 4 de junio de 2009, promulgada de hecho el 3 de julio de 2009. BOCBA no 3215 del 15 de julio de 2009.

Monumento a las víctimas del terrorismo de Estado. Parque de la memoria, Presentación, Folleto informativo, Buenos Aires, marzo de 2016, archivo personal.

Webgrafía (Ultima consulta septiembre de 2018): 
El Río y los desaparecidos:

http://www.fotofest.org/ff2004/exhibitions_zout.htm

Parque de la memoria:

http://www.buenosaires.gob.ar/patrimonio-cultural/parque-de-la-memoria

http://parquedelamemoria.org.ar/

http://hd.clarin.com/tagged/ObamaEnArgentina

https://www.fundacionkonex.org/premios2012-artes-visuales

http://www.arquitecturapanamericana.com/parque-de-la-memoria/

Pablo Míguez:

http://www.fotofest.org/ff2004/exhibitions_zout.htm

https://www.youtube.com/watch?v=hHssrns50zs

\section{NOTAS}

1. Jean-Louis Deotte, "Las paradojas del acontecimiento de una desaparición", en Memorias en conflicto, Raynald Belay, Jorge Bracamonte, Carlos Iván Degregori y Jean Joinville Vacher (éd.), Lima, Institut français d'études andines, Instituto de Estudios Peruanos, Embajada de Francia en el Perú, Red para el Desarrollo de las Ciencias Sociales en el Perú, 2004, p. 326.

2. Fuente: Autor desconocido.

3. De ahora en más MDDHH.

4. Se denominan "Vuelos de la muerte" a la metodología empleada durante el terrorismo de Estado para hacer desaparecer los opositores ideológicos-políticos arrojándolos desde aviones militares hacia el río o el mar. Esta metodología de crímenes de masa fue utilizada para no dejar huellas del accionar delictivo tal como fuera comprobado en sede judicial. El 30 de noviembre de 2017, después de transcurridos cinco años de juicio, la causa conocida como ESMA III o ESMA Unificada concluyó con 29 condenas a prisión perpetua, 19 condenas a penas entre 8 y 25 años y 6 absoluciones. Durante estos años, se investigaron "las violaciones a los derechos humanos que tuvieron lugar entre el 24 de marzo de 1976 y el 10 de diciembre de 1983. [Es decir] los delitos cometidos dentro del ámbito de la Escuela Mecánica de la Armada (ESMA) o bien por quienes desarrollaron tareas en la Unidad de Tareas 3.3.2, perteneciente al Grupo de Tareas 3.3 -con base operativa en esa dependencia naval-, [y que] dieron lugar a operativos tanto en la Ciudad de Buenos Aires como en varias localidades del Gran Buenos Aires. [Estos operativos estaban] destinados principalmente a privar de su libertad a diferentes personas con el objeto de interrogarlas mediante la aplicación de tormentos y obtener nombres, direcciones y otros datos generales tendientes a desarticular agrupaciones políticas y sociales. En la mayoría de los casos, las personas privadas de su libertad fueron eliminadas físicamente. De los testimonios de estas actuaciones se desprende que la metodología de eliminación consistía en quemar los cuerpos sin vida o arrojarlos al mar mediante los denominados 'vuelos de la muerte'. [...]". https:// www.cij.gov.ar/esma.html. Consultado en octubre 2018. Volveremos sobre este tema más adelante.

5. En este mismo número, en el Dossier creativo, puede encontrarse en "Pablo y el río" de Claudia Torre otra perspectiva sobre el mismo tema (N. de los E.).

6. Cfr. Gilles Deleuze, Diferencia y repetición, trad. de María Silvia Delpy y Hugo Beccacece, Buenos Aires, Amorrortu. 2002. 
7. En su versión original: "Les lieux de mémoire ne vivent que de leur aptitude à la métamorphose". Pierre Nora, "Entre Mémoire et Histoire", en Pierre Nora (ed.), Les lieux de mémoire, vol. 1 (La République), Paris, Gallimard, 1997. La traducción me pertenece.

8. A los efectos del monumento se consideran víctimas los desparecidos y asesinados durante las dos últimas dictaduras cívico-militares y el periodo intermedio. "En el Monumento a las Víctimas del Terrorismo de Estado se encuentran los nombres de los detenidos-desaparecidos y/o asesinados por el accionar represivo perpetrado por el Estado en el periodo 1969-1983. El Monumento está compuesto por cuatro estelas de hormigón que contienen treinta mil placas de pórfido patagónico de las cuales alrededor de nueve mil se encuentran grabadas con los nombres de hombres, mujeres, niñas y niños víctimas de la violencia ejercida desde el Estado. Los nombres se encuentran ubicados cronológicamente, por año de desaparición y/o asesinato, y por orden alfabético; además, se indica la edad de las víctimas y se señalan los casos de mujeres embarazadas" cfr: http://parquedelamemoria.org.ar/sobre-el-monumento-a-las-victimas-delterrorismo-de-estado/. La nómina de las víctimas se conformó a partir de distintas fuentes (Comisión Nacional sobre Desaparición de Personas (CONADEP), denuncias ante la Secretaría de Derechos Humanos del Ministerio de Justicia y Derechos Humanos de la Nación y el Poder Judicial, la base de Datos del Equipo Argentino de Antropología Forense y base de datos de la Asociación Abuelas de Plaza de Mayo). La nómina del Monumento continúa abierta a la incorporación de nuevos nombres. Para ello se han dejado espacios vacíos y se concibieron las 30.000 placas.

9. Al respecto pueden ser consultados los trabajos de Faletto (1987) y de Melucci (1994).

10. Momentos claves del calendario colectivo de acciones son los jueves, 24 de marzo, 30 de agosto, 16 de septiembre, 18 de septiembre, 10 de diciembre, primer jueves de diciembre.... Para ampliar este y los conceptos que siguen, ver Insua (2001)

11. En 1981 en el contexto de la primera Marcha de la Resistencia, ante otras organizaciones o activistas que se oponían, las Madres impusieron este nombre para definir la acción justificándolo de la manera siguiente: Decía Hebe de Bonafini “[...] no es nada más que lo hacemos. Resistir". Ver Historia de las Madres, Buenos Aires, Asociación Madres de Plaza de Mayo, 1999.

12. Estos son: Abuelas de Plaza de Mayo, Madres de Plaza de Mayo-Línea Fundadora, Familiares de Desaparecidos y Detenidos por Razones Políticas, Fundación Memoria Histórica y Social Argentina, Centro de Estudios Legales y Sociales, Asociación Civil Buena Memoria, Asamblea Permanente por los Derechos Humanos, Liga Argentina por los Derechos del Hombre, Movimiento Ecuménico por los Derechos del Hombre, Servicio Paz y Justicia.

13. En Horacio Verbistky, El vuelo, trad. Anatole Muchnik, Paris, Ed Dagorno, 1995, p. 16.

14. Ibidem, p. 66.

15. Escrachar: Identificar, señalar, marcar públicamente a un responsable directo del Terrorismo de Estado de los años '70 enfrentándolo en su propio espacio de acción oponiéndole en el enfrentamiento el cuerpo mismo de sus víctimas y afectados directos, en Insua (2001)

16. Asociación Madres de Plaza de Mayo, Nuestras consignas (actuales), Folleto, Buenos Aires, 1999.

17. Declaraciones de Raquel Robles al diario Página 12, 26 de marzo de 1999.

18. Finamente la frase seria esculpida en el Monumento definitivo.

19. Fuente: "El parque en fotos". Foto institucional del Parque de la memoria.

20. En "Justificativo del proyecto arquitectónico parque de la memoria. BAQ 2014". http:// www.arquitecturapanamericana.com/parque-de-la-memoria/

21. En Bases y reglamento del Concurso de esculturas del Parque de la Memoria, 1999.

22. Graciela Silvestri, "El arte en los límites de la representación", en revista Punto de Vista, n68, diciembre 2000, Buenos Aires.

23. Así lo afirma la Comisión Pro-Monumento: "El arte es una de las principales herramientas para la elaboración de la memoria colectiva" en "Proyecto para no olvidar", Hochbaum Nora y 
Battini Florencia (coord..), Monumento a las víctimas del terrorismo de Estado. Parque de la memoria, Buenos Aires, Consejo de gestión de Parque de la memoria/Gobierno de la Ciudad Autónoma de Buenos Aires, 2010, p. 25.

24. 12 fueron elegidas por concurso y 6 seleccionadas especialmente.

25. Fuente: Cara interna del Folleto "Monumento a las Victimas del Terrorismo de Estado. Parque de la Memoria". Octubre de 2016.

26. Graciela Silvestri, "El arte en los límites de la representación", op. cit. Con los "tres recordatorios" Silvestri se refiere aquí a los memoriales destinados a la AMIA y al Obispo Segura. El memorial en homenaje a las víctimas del atentado de la AMIA se inauguró el 16 de julio de 2014 en el Paseo de la Costa (Vergara y el río, Ciudad de Vicente López). El subrayado proviene del texto original.

27. Esta bandera es utilizada particularmente por las organizaciones del MDDHH para marchar por las calles en la ocasión del 24 de marzo.

28. Fuente: foto propia.

29. Cfr. Ernesto Laclau, Emancipación y diferencia, Buenos Aires, Ariel, 1996.

30. "Adolescentes", Informe de la Comisión Nacional sobre la Desaparición de Personas, CONADEP, Nunca Mas, Buenos Aires, Eudeba, 2003, p. 323.

31. Comisión Pro-Monumento a las Víctimas del Terrorismo de Estado, Escultura y Memoria, Buenos Aires, Eudeba, 2000, p. 250.

32. El número de 250 adolescentes desaparecidos esta tomado del informe CONADEP. Ahora bien, ese número fue evolucionando con los años y se presume que fueron muchos más los jóvenes desaparecidos.

33. Su caso permitió las condenas a las militares expresadas en la sentencia del Tribunal Oral en lo Criminal Federal $\mathrm{N}^{\circ} 4$, causa 1487 del 23 de septiembre de 2011.

34. Declaración de Lila Pastoriza en el Juicio de las Juntas. Transcripción literal.

35. Fuente: foto que ilustra el artículo de Lila Pastoriza en el Diario Página 12, Buenos Aires, 24 de marzo de 1998.

36. Por ejemplo, en este caso, según relató Elena Alfaro, sobreviviente del Vesubio, en el Juicio a las Juntas, Pablo fue torturado delante de su madre para obligarla a ceder su casa a los secuestradores.

37. Ibidem. El comentario entre paréntesis me pertenece.

38. Lila Pastoriza, "No se sabía qué hacer con él. La historia de Pablo Míguez, desaparecido de la ESMA cuando tenía catorce años", en diario Página 12, 24 de marzo de 1998, Buenos Aires, p. 5.

39. Fuente: Comisión Monumento a las Víctimas del Terrorismo de Estado, Escultura y Memoria, p. 250.

40. Claudia Fontes, "La labor de los artistas es inventar maneras de entender el mundo", en diario El Tribuno, Salta, 7 de octubre 2016.

41. Comisión Pro-Monumento a las Víctimas del Terrorismo de Estado, Escultura y Memoria, op. cit ., p. 250.

42. El nombre de la sala PAyS hace referencia al grito conmemorativo "30000 compañeros desaparecidos presente, 30000 compañeros desaparecidos presente, 30000 compañeros desaparecidos presente, ahora y siempre".

43. Fuente: Fotos propias tomadas en el Parque de la memoria en octubre de 2016. La primera desde el camino a la explanada donde está previsto el observatorio de la obra, la segunda en el observatorio y la tercera ayudándonos con un teleobjetivo desde el mismo lugar. La primera de ella es similar a la que podría haber sido sacada desde la sala PAys.

44. Comisión Pro-Monumento a las Víctimas del Terrorismo de Estado, Escultura y Memoria, op. cit ., p. 250.

45. Fuente: Foto propia tomada en el Parque de la memoria en octubre de 2016. Dice la placa: "La escultura articula los conceptos de aparición/desaparición y se basa en el retrato de un 
adolescente que fue desaparecido cuando solo tenía catorce años. La obra fue inspirada en el caso de Pablo Míguez quien, si aun viviera, tendría hoy la misma edad que la artista".

46. Claudia Fontes, op. cit.

47. Fuente: Foto propia tomadas en el Parque de la memoria en octubre de 2016. Entrada lateral del Parque de la Memoria. Separación física entre el paseo de los pescadores y el Parque de la Memoria.

48. "No es que haga diferencias, pero es un caso especial", dijo Lila Pastoriza. "A 33 años no se sabe nada de lo que pasó con Pablo, nunca nadie dijo nada. No sé por qué razón lo llevaron por distintos campos, si es que estaba tomada una decisión, si la estaban retardando. Lo sometieron a un deambular por los centros clandestinos, hay puntas para investigar qué pasó con él, hay gente que lo decidió y gente que lo ejecutó, que eran los dueños de la vida. Que hablen, no porque eso vaya a resolverlo, sino que permitiría avanzar con el conocimiento de la verdad. Si la conciencia les pesa, decirlo los va a aliviar." Entrevista a Lila Pastoriza de Alejandra Dandan, "No se sabe nada de lo que pasó con Pablo", diario Página 12, 11 de octubre de 2010, Buenos Aires.

49. Cfr. Didi-Huberman Georges, Images malgré tout, Paris, Les Editions de Minuit, 2003.

50. Comisión Pro-Monumento a las Víctimas del Terrorismo de Estado, Escultura y Memoria, Proyecto parque de la Memoria, Buenos Aires, Gobierno de Buenos Aires/ Comisión Monumento a las Víctimas del Terrorismo de Estado, 2003.

51. Patricia Tappata de Valdez, "El Parque de la memoria en Buenos Aires" en Elisabeth Jelin y Victoria Langland (comps.), Monumentos, memoriales y marcas territoriales, Madrid, Siglo XXI, 2003, p. 45.

52. Fuente: Juano Tesone, diario Clarín, 26 de marzo de 2016

\section{RESÚMENES}

La Reconstrucción del retrato de Pablo Míguez de Claudia Fontes es una escultura emplazada en el Parque de la Memoria, espacio público ubicado en la costanera porteña, frente al Río de la Plata, erigido para conmemorar a los desaparecidos y asesinados por el terrorismo de Estado que asoló la Argentina desde mediados de los años 70 hasta el regreso de la democracia constitucional en diciembre de 1983. El interés que produce esta estatua se origina en que ella, más que cualquiera de las otras obras que forman parte del conjunto poli-escultural del Parque de la Memoria, se sitúa en el punto radical de fractura entre el reconocimiento y la sensibilidad del sentido que Gilles Deleuze atribuye a la génesis del acto de pensar y al pensamiento mismo: al "objeto del encuentro fundamental". La Reconstrucción... no solo actúa como objeto de encuentro por su relación fáctica entre el río y la ciudad, sino que es el lugar mismo de creación del encuentro e irrumpe en el pensamiento cuando éste es incapaz de producir el reconocimiento del objeto del acto de pensar forzando de esta manera a que el mundo de lo sensible intervenga.

La Reconstruction du portrait de Pablo Míguez de Claudia Fontes, est une sculpture installée dans le Parc de la Mémoire, espace public situé dans la rivière du fleuve de La Plata érigé pour commémorer les disparus et assassinés par le terrorisme d'Etat instauré en Argentine depuis la moitie des années 70 jusqu'au retour de la démocratie constitutionnelle le 10 décembre 1983. L'intérêt que porte cette sculpture plus que n'importe quelle autre de l'ensemble mémoriel polisculptural, est produit par le fait qu'elle se situe dans le point radical de fracture entre la reconnaissance de la disparition forcée de personnes et la sensibilité du sens à l'origine de la pensée qu'est-ce qu'un disparu. En termes de Gilles Deleuze, la Reconstruction est l'objet de la 
rencontre fondamentale ». Cela n'est pas une conséquence du fait qu'elle se trouve exactement entre la ville et le fleuve, premier espace de rencontre, sinon parce qu'elle est le lieu précis de création de la rencontre. La Reconstruction fait irruption dans la pensée de l'observateur lorsqu'elle est incapable de produire la reconnaissance de l'objet de la pensée faisant en sorte de cette manière que le monde du sensible intervienne pour compléter ou attribuer du sens au corps qu'elle représente.

The Reconstruction of the Portrait of Pablo Míguez by Claudia Fontes is a sculpture located in the Parque de la Memoria, a public space located on the Buenos Aires waterfront, facing the Río de la Plata, erected to commemorate the disappeared and murdered by the State terrorism that Argentina ravaged from the mid-70s until the return of constitutional democracy in December 1983. The interest that this statue produces originates in that it, more than any of the other works that are part of the poly-sculptural set of the Park of Memory, is situated at the radical point of fracture between the recognition and sensitivity of the meaning that Gilles Deleuze gives to the genesis of the act of thinking and to thought itself: to the "object of the fundamental encounter". Reconstruction ... not only acts as an object of encounter because of its factual relationship between the river and the city, but it is the very place of creation of the encounter and bursts into thought when it is incapable of producing the recognition of the object of the act of thinking thus forcing the sensitive world to intervene.

\section{ÍNDICE}

Mots-clés: disparus, commémoration, victimes innocentes, politique de la mémoire

Palabras claves: desaparecidos, conmemoración, víctimas inocentes, políticas de la memoria

Keywords: missing, commemoration, innocent victims, memory politics

\section{AUTOR}

\section{MYRNA INSUA}

Université Paris Est-Créteil y Universidad de Salamanca

Investigadora asociada del Institut National de l'Audiovisuel (INA)

minsuabelfer@gmail.com 